\title{
An aircraft gas chromatograph-mass spectrometer System for Organic Fast Identification Analysis (SOFIA): design, performance and a case study of Asian monsoon pollution outflow
}

\author{
Efstratios Bourtsoukidis, Frank Helleis, Laura Tomsche, Horst Fischer, Rolf Hofmann, Jos Lelieveld, and \\ Jonathan Williams \\ Department of Atmospheric Chemistry, Max Planck Institute for Chemistry, Mainz, 55128, Germany
}

Correspondence: Efstratios Bourtsoukidis (e.bourtsoukidis@mpic.de)

Received: 19 June 2017 - Discussion started: 10 July 2017

Revised: 7 November 2017 - Accepted: 21 November 2017 - Published: 22 December 2017

\begin{abstract}
Volatile organic compounds (VOCs) are important for global air quality and oxidation processes in the troposphere. In addition to ground-based measurements, the chemical evolution of such species during transport can be studied by performing in situ airborne measurements. Generally, aircraft instrumentation needs to be sensitive, robust and sample at higher frequency than ground-based systems while their construction must comply with rigorous mechanical and electrical safety standards. Here, we present a new System for Organic Fast Identification Analysis (SOFIA), which is a custom-built fast gas chromatography-mass spectrometry (GC-MS) system with a time resolution of 2-3 min and the ability to quantify atmospheric mixing ratios of halocarbons (e.g. chloromethanes), hydrocarbons (e.g isoprene), oxygenated VOCs (acetone, propanal, butanone) and aromatics (e.g. benzene, toluene) from sub-ppt to ppb levels. The relatively high time resolution is the result of a novel cryogenic pre-concentration unit which rapidly cools ( $\sim 6^{\circ} \mathrm{C} \mathrm{s}^{-1}$ ) the sample enrichment traps to $-140^{\circ} \mathrm{C}$, and a new chromatographic oven designed for rapid cooling rates $\left(\sim 30^{\circ} \mathrm{C} \mathrm{s}^{-1}\right)$ and subsequent thermal stabilization. SOFIA was installed in the High Altitude and Long Range Research Aircraft (HALO) for the Oxidation Mechanism Observations (OMO) campaign in August 2015, aimed at investigating the Asian monsoon pollution outflow in the tropical upper troposphere. In addition to a comprehensive instrument characterization we present an example monsoon plume crossing flight as a case study to demonstrate the instrument capability. Hydrocarbon, halocarbon and oxygenated VOC data from SOFIA are compared with mixing ratios of carbon monoxide $(\mathrm{CO})$ and methane $\left(\mathrm{CH}_{4}\right)$, used to define the pol-
\end{abstract}

lution plume. By using excess (ExMR) and normalized excess mixing ratios (NEMRs) the pollution could be attributed to two air masses of distinctly different origin, identified by back-trajectory analysis. This work endorses the use of SOFIA for aircraft operation and demonstrates the value of relatively high-frequency, multicomponent measurements in atmospheric chemistry research.

\section{Introduction}

Despite their generally low ambient concentrations, organic trace gases can have significant impacts on atmospheric chemistry (Williams, 2004). Halogenated organic compounds are capable of destroying both tropospheric and stratospheric ozone (Molina and Rowland, 1974; Read et al., 2008; Saiz-Lopez et al., 2012; Wang et al., 2015), and thus altering the oxidative capacity of the atmosphere (Parrella et al., 2012; Baker et al., 2016), with prominent examples being the chlorofluorocarbons (CFCs) and the hydrochlorofluorocarbons (HCFCs). Their industrial replacements, i.e. hydrofluorocarbons (HFCs), may have lower stratospheric ozone depletion potentials but they can act as potent greenhouse gases (Velders et al., 2009). In addition, oxygenated volatile organic compounds (OVOCs) and simple hydrocarbons (HCs), whose emissions are associated with both biogenic and anthropogenic sources, play a central role in the production and destruction of key atmospheric oxidants such as the hydroxyl radical (OH) (Kley, 1997; Atkinson, 2000; Monks, 2005; Lelieveld et al., 2016) and ozone (Pusede and 
Cohen, 2012). It is therefore essential to monitor their atmospheric abundance and understand their source-sink dynamics, particularly in the chemically sensitive but poorly accessible region of the upper troposphere and lower stratosphere.

For over sixty years, organic trace gases in the atmosphere have been measured by acquiring air samples in the field, using pressurized metal/glass containers or adsorbent-filled tubes, and subsequently measuring them "off-line" in the laboratory. A commonly used analytical technique for such samples has been gas chromatography (GC), coupled to detectors such as the mass spectrometer (MS), the flame ionization detector (FID) and the electron capture detector (ECD) (e.g. Haagen-Smit et al., 1956; Colman et al., 2001; Colomb et al., 2006; Williams et al., 2007; Pollmann et al., 2008; Lerner et al., 2017). While this approach allows for straightforward sampling in remote regions, and in the upper troposphere using research aircraft or balloons, the sample frequency is limited by the number of containers available and it is prone to interference from surface-related artefacts (especially for the most reactive species; Plass-Dülmer et al., 2006). To achieve higher time resolution and hence data density in atmospheric measurements, several "on-line" instrumental techniques have been developed based on ionization mass spectrometry (e.g. Arnold and Hauck, 1985; Crutzen et al., 2000; Sprung et al., 2001; Blake et al., 2006; Le Breton et al., 2012). These methods use positively or negatively charged species to ionize the substances of interest prior to their detection in a mass spectrometer. While these techniques enable high-resolution sampling (typically $1 \mathrm{~s}-1 \mathrm{~min}$ ), as they do not require a pre-concentration or separation, they suffer from lower molecular specificity compared to GC-MS, as multiple species may contribute to a given mass signal. Therefore, provided it can be made to measure fast enough, gas chromatography (GC) coupled with a mass spectrometer (MS) can be an extremely powerful tool in atmospheric research.

In recent years, there has been considerable focus on optimizing GC analysis for speed (Mastovska and Lehotay, 2003). This has led to a new generation of fast GC systems that can be applied in airborne research since they combine high time resolution and mass selectivity. Apel et al. (2003) developed the first fast GC-MS system for airborne measurements of VOCs and halocarbons (Trace Organic Gas Analyzer, TOGA; see also Apel and UCAR/NCAR - Earth Observing Laboratory, 2016; Hornbrook et al., 2011; Apel et al., 2010, 2012). TOGA uses a custom-built liquid nitrogen $\left(\mathrm{LN}_{2}\right)$ fuelled system to cool sample enrichment traps down to $-130^{\circ} \mathrm{C}$ enabling a sample to be taken every $2-5 \mathrm{~min}$. To our knowledge, three other fast GC systems have since been designed for aircraft operation: GhostMS (Sala et al., 2014), HCG (Jäger, 2014) and $\mu$ Dirac (Gostlow et al., 2010). None of the three require the use of a liquid cryogen and all have been successfully operated in aircraft, Zeppelin or balloon campaigns. The use of $\mathrm{LN}_{2}$ for cryogenic trapping has both advantages and disadvantages, which are discussed in Sect. 4.

The objective of this paper is to present a comprehensive description of the new fast GC-MS instrument, called "System for Organic Fast Identification Analysis (SOFIA)", designed for airborne measurements. In Sect. 2 a detailed description of the major components and sampling characteristics is provided along with the instrument specifications, as defined under laboratory and field conditions. In Sect. 3 we demonstrate the capabilities of SOFIA by presenting an example from the OMO aircraft campaign, flying over the Arabian Peninsula in August 2015 to intercept pollution plumes convected to the upper atmosphere in the Indian monsoon system. We demonstrate the usefulness of fast GC-MS measurements by studying the mixing ratios of selected chloromethanes (chloromethane, $\mathrm{CH}_{3} \mathrm{Cl}$; dichloromethane, $\mathrm{CH}_{2} \mathrm{Cl}_{2}$; chloroform, $\mathrm{CHCl}_{3}$; and carbon tetrachloride, $\mathrm{CCl}_{4}$ ), hydrocarbons (isoprene, $\mathrm{C}_{5} \mathrm{H}_{8}$; benzene, $\mathrm{C}_{6} \mathrm{H}_{6}$; and toluene, $\mathrm{C}_{7} \mathrm{H}_{8}$ ), OVOCs (propanal, $\mathrm{C}_{3} \mathrm{H}_{6} \mathrm{O}$ and acetone, $\mathrm{C}_{3} \mathrm{H}_{6} \mathrm{O}$ ) and sulfur containing species (carbon disulfide, $\mathrm{CS}_{2}$ ) in a pollution plume, and discuss the technical and scientific implications.

\section{Material and methods}

The system described below has been designed and constructed for use on-board the German High Altitude Long Range aircraft (HALO), a Gulfstream G550 aircraft, operated by the German Aerospace Organization (DLR). Operation on-board a high-flying aircraft such as HALO requires that the analytical system can perform reliably over the widely varying conditions of external temperature (40 to $-60^{\circ} \mathrm{C}$ ) and pressure $(1000-200 \mathrm{mb}$ ). In addition, the internal cabin conditions also change and all relevant parameters must be measured for subsequent performance assessments. In the case of the SOFIA system, an additional challenge arises through the use of a liquid nitrogen $\left(\mathrm{LN}_{2}\right)$ cryogenic system, because the $\mathrm{LN}_{2}$ evaporation rate in the container is strongly pressure and temperature dependent, thus safe and accurate pressure control within the cryogenic system is essential. The following sections present a detailed description of the major components of the SOFIA GCMS system. They comprise of a sampling system overview (Sect. 2.1), a detailed description of the cryogenic trapping method (Sect. 2.2) and chromatographic GC oven (Sect. 2.3), a characterization of the detection and quantification unit using standard gas experiments (Sect. 2.4), a weight characterization (Sect. 2.5) and a description of the process control and software (Sect. 2.6). Section 2.7 presents laboratory experiments while the last part (Sect. 2.8) reports the analytical specifications during the example flight presented in the "case study" section, which was part of the first field deployment of the instrument. 


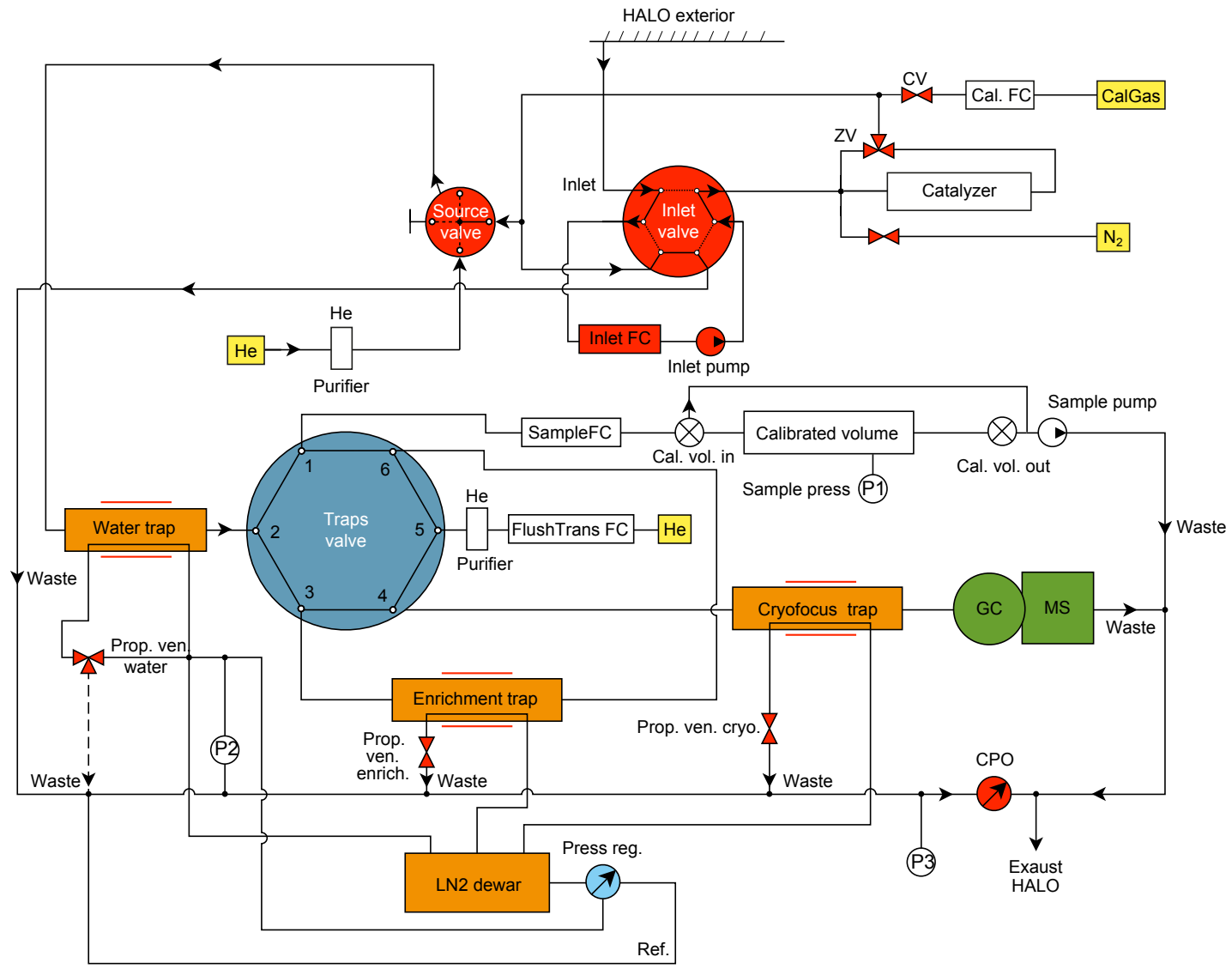

Figure 1. Schematic overview of SOFIA.

\subsection{Sampling overview}

A schematic overview of the SOFIA system is presented in Fig. 1. Air is drawn by the inlet pump (described in Sect. 2.1.1) through the sampling line, which extends outside the aircraft fuselage. The sample pre-concentration then follows in three stages (described in Sect. 2.2; illustrated in the Supplement, Fig. S1). First, the air is pumped through the cooled water trap, where $\mathrm{H}_{2} \mathrm{O}$ is selectively removed from the airstream, and then through the low-temperature enrichment trap where VOC molecules are retained. During sampling, a flow controller (Fig. 1; SampleFC) is used to regulate the sampling flow, and the pressure change inside a sampling volume unit (Fig. 1; Calibrated volume) is used for accurate sample volume determination. In the second stage, the enrichment trap is heated and the volatiles are transferred to the cryofocus trap, which is a narrow $(0.25 \mathrm{~mm})$ inert chromatography column with low volume to optimize the subsequent injection. In the third stage, the cryofocus trap is heated rapidly and the sample is injected into the chromatography column housed in the oven (denoted GC in Fig. 1), where it is separated prior to ionization and detection of the peak sequence by the mass spectrometer (denoted MS in Fig. 1).

\subsubsection{Inlet system}

Air was drawn into the aircraft through a forward-facing trace gas inlet (TGI; Enviscope GmbH) (Fig. 2; Wendisch et al., 2016). The TGI body is constructed of aluminium (WL.Number $3.4364, \mathrm{~T} 7351$ ) and continuously heated to $40^{\circ} \mathrm{C}$. Inside the TGI, PFA tubes $\left(1 / 2^{\prime}\right.$ for the horizontal external tube and $1 / 4^{\prime}$ for the perpendicular tube) are used for the air streams. The main air flow is parallel to the flight direction and the inlet pump of SOFIA draws air from the Tpiece inside the TGI, perpendicular to the flight direction. In the cabin, a heated Teflon line $\left(1 / 4^{\prime}, 0.635 \mathrm{~cm} ; 2 \mathrm{~m}\right.$ length, $40^{\circ} \mathrm{C}$ ) brings the air into the inlet valve (Fig. 1). The inlet system of SOFIA was designed to compress ambient air to standard pressure at a minimum flow rate of $200 \mathrm{sccm}$ in $\sim 15 \mathrm{~km}$ altitude. The inlet pump and flow controller pressurize the sample to enhance the throughput in the inlet tubes $(200 \mathrm{sccm})$ over the actual sampling flow $(40 \mathrm{sccm})$ (Fig. S1). Under such conditions a maximum residence time of $15 \mathrm{~s}$ can be maintained at the highest flight altitudes in the flow loop from the aircraft inlet through the zero/calibration system to the sampling point. The compression ratio of single-stage allPFA Teflon diaphragm pumps was not sufficient to fulfil our requirements, and dual-stage pumps would push the overall 


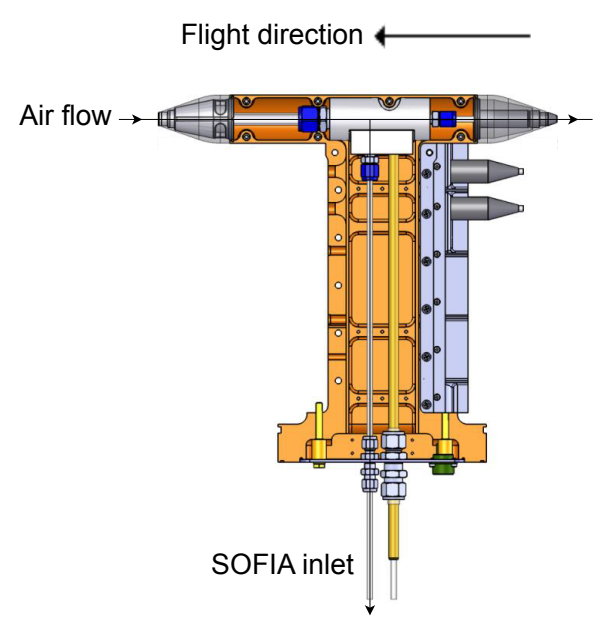

Figure 2. Trace gas inlet (TGI) installed on-board HALO.

system beyond the weight and size limits. Therefore, three small identical PFA pumps (NMP 850KNDC, KNF Global Strategies AG) were used on the low-pressure inlet in parallel, and since the maximum pressure of the single stage was not enough it was backed by a fourth pump connected to the high-pressure exit upstream of the sampling system (all four pumps are illustrated as a single one in Fig. 1).

Since even small leaks in the low-pressure part of the inlet system can cause interferences, the pumps' tightness was tested prior to integration. It was found that the pump heads, as sold, leaked severely across the edge of the diaphragm. This issue was solved by fitting watch chronometer O-rings around the diaphragm of the individual pumps. The O-rings were fitted outside the original Teflon diaphragm, sealing the edges of the pump heads so that they are not in contact with the sample. The pressure in the sampling system was maintained by a mechanical diaphragm pressure controller downstream of the sampling point (see Sect. 2.2.3).

Three gas cylinders ( $2 \mathrm{~L}$, Luxfer, USA) are required for normal operation of SOFIA and they are located at the bottom of the instrument's rack. Helium (6.0 Westfalen AG, Germany) is used as carrier gas and a multicomponent gas standard (Apel-Riemer Environmental, Inc., USA) is used for in situ calibrations. The third cylinder contains pressurized $\mathrm{N}_{2}$ (6.0, Westfalen AG, Germany) and is used for diagnostic purposes such as inlet blanks and to prevent jet-fuel vapours being sampled during taxiing. In addition, the $\mathrm{N}_{2}$ gas cylinder serves as zero air in regions that ambient sampling is not permitted. Blanks that have been obtained in such manner contain no peaks unless a leak or contamination of the inlet is present. Therefore the $\mathrm{N}_{2}$ cylinder has proven to be a reliable addition for both inlet testing and standby operation.

\subsubsection{Zero/calibration unit}

Directly downstream of the inlet system, ambient air was either sent directly to the sampling loop or through an oxidizing catalyst tube, depending on the three-way zero valve (Fig. 1; ZV) position. The platinum bead packed catalyzer (PN 206016, Sigma Aldrich, USA) was maintained at $350^{\circ} \mathrm{C}$ and the outflow used as VOC free air, since under these conditions all VOC measured were converted entirely to $\mathrm{CO}_{2}$. The catalyzer does not significantly affect ambient water concentrations and so keeps sample humidity in calibration and zero modes the same as ambient conditions. In calibration mode, the calibration valve (Fig. 1; CV) was activated to allow a multicomponent calibration gas mixture (about $50 \mathrm{ppb}$ of 79 compounds, Apel-Riemer Environmental, Inc., USA) to enter via a $5 \mathrm{sccm}$ flow controller (Bronkhorst, Germany) into the line exiting the unit. By modifying the inlet and the calibration gas mixture flows, a wide range of mixing ratios is achieved and used for the calibration curves.

\subsubsection{Multi-position valves}

During operation, two multiple position valves (Fig. 1; Source valve, Traps valve; VICI, Germany) were operated concurrently. The Source valve is a 4-port valve that switches gaseous input either to a zero/calibration unit (including ambient air), a helium line or to a plug. The plugged position is used for diagnostic purposes, in particular for leak tests during flight preparation. When running continuously, the Source valve was set to helium source except during sampling mode. The Traps valve is a 6-port valve that connects the water, enrichment, and focus traps. The Traps valve switches between SAMPLE and INJECT modes. In the SAMPLE position, preparation of the next sampling cycle and sampling is done in parallel, with the last sample driven through the isolated cryofocus trap to the GC column and the detector. In INJECT position, the enrichment part of the sampling loop is connected to the injection loop to transfer the sample to the cryofocus trap, while the water trap is purged in parallel to vent. An extended illustration of the flow paths can be found in the Supplement (Fig. S1).

\subsubsection{The sampling volume unit}

The sample volume measurement unit is connected to the Traps valve downstream of the traps. It consists of a $100 \mathrm{~mL}$ flow controller, a calibration volume tank $(432 \mathrm{~mL})$, two solenoid valves (ET-2, $24 \mathrm{~V}$, Clippard) to direct the sample flow into the sampling volume or bypass it, a sample diaphragm pump (vacuum pump; Pfeiffer MVP 006-4) and a NTC temperature sensor (Y3k-type thermocouple). The process controller isolates the pump from the sampling volume during sampling, monitors the pressure difference accumulated and calculates the air volume sampled, additionally taking the temperature reading into account. When not in sam- 
pling mode, the sample volume is connected to the sample pump to prepare for the next sampling cycle.

\subsection{Cryogenic trapping}

\subsubsection{Design and implementation}

The main objective of the cryogenic concentration systems is to achieve the minimum cycle time between the required temperature set-points (i.e. -160 to $120^{\circ} \mathrm{C}$ ) with minimum $\mathrm{LN}_{2}$ consumption. The total operation time between $\mathrm{LN}_{2}$ refilling is $17 \mathrm{~h}$ and covers the maximum flight duration $(10 \mathrm{~h})$ and associated pre-flight ground tests $(2 \mathrm{~h})$. The cryogenic concentration system (Fig. 3) is positioned on top of the $\mathrm{LN}_{2}$ container. It consists of the pressure-tight container-top plate with three cooler assemblies mounted on top of each other. In accordance with the target temperatures of each trap, the cryofocus trap is housed at the bottom, closest to the $\mathrm{LN}_{2}$, the middle one is used for the enrichment trap and the upper one supports the water trap. Good thermal insulation of the whole arrangement is achieved by thin-walled, stainless steel tubing and housings surrounded by an Aerogel powder (Silica granules, InnoDämm, Germany) filling up a powdertight, 3-D printed elastomer enclosure.

Enrichment and cryofocus trap housings have a tube reaching down into a $\mathrm{LN}_{2}$ container directly below the top plate of the container, from where $\mathrm{LN}_{2}$ is drawn if the outlet pressure of the housing is $\sim 50 \mathrm{mbar}$ lower than the pressure in the container. The water trap housing takes cold $\mathrm{N}_{2}$ gas off of the headspace of the container, because its cooling power demands are much smaller. With the cooling tubes immersed in the $\mathrm{LN}_{2}$, trap operations do not interfere with each other, because the change of liquid level is minimal on changing individual cooler power. The system can therefore transport $\mathrm{LN}_{2}$ to rapidly cool down the enrichment and cryofocus traps (Fig. 3). This approach makes use of the latent heat energy (as opposed to cooled gas solutions), optimizing the cycle time.

The three traps are made of straight thin-walled and uncoated stainless steel tubing (type 1.4301, Günther Lämmermeir OHG, Germany). The inner diameter of the water trap is $1 / 8^{\prime \prime}(0.318 \mathrm{~cm})$ and the enrichment trap $1 / 16^{\prime \prime}$ $(0.159 \mathrm{~cm})$. The water and enrichment traps are in contact with the sample. The cryofocus trap $\left(1 / 16^{\prime \prime}\right)$ acts as the housing of a $0.25 \mathrm{~mm}$ inert chromatographic column (PN 160255-10, Agilent Technologies, USA). Trap temperature measurement is achieved by use of a $100 \mu \mathrm{m}$ (Omega Engineering, Germany) wire thermocouple attached via a thin-walled PFA tube.

\subsubsection{Liquid nitrogen container}

The $\mathrm{LN}_{2}$ container ( $\mathrm{LN}_{2}$-Badkryostat, CryoVac, Germany) has a usable volume of $10.5 \mathrm{~L}$, which is sufficient for $\sim 17 \mathrm{~h}$ of continuous operation at a cycle time of $3.1 \mathrm{~min}$. It is a vac-
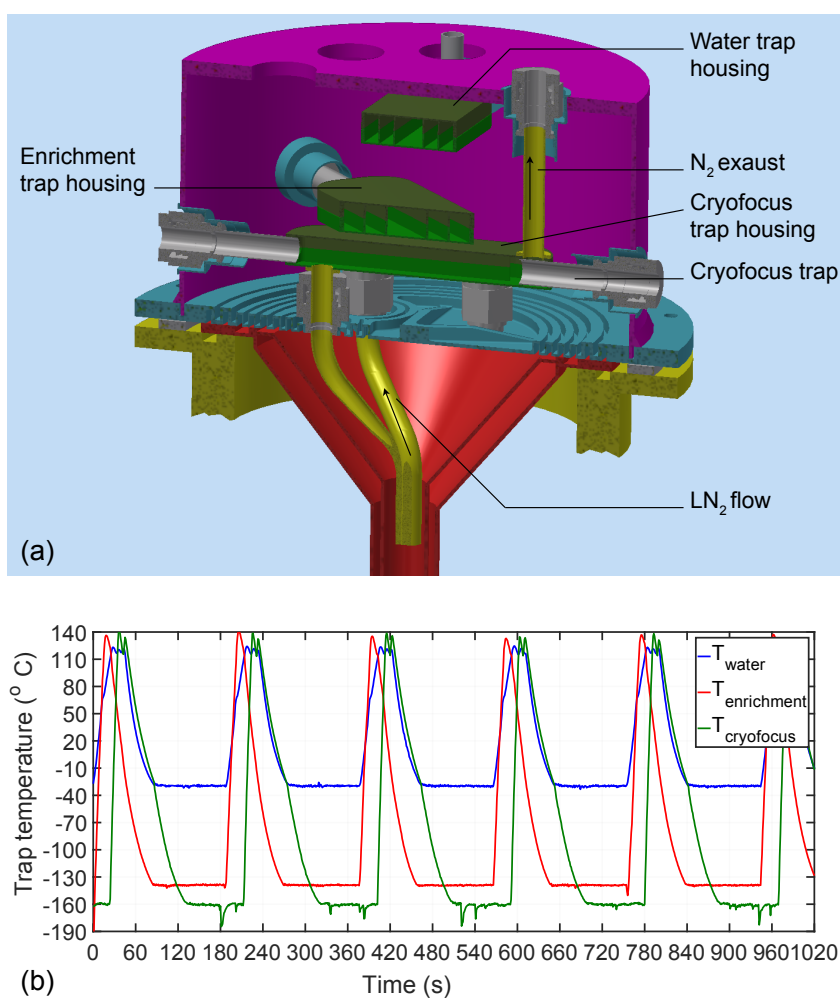

Figure 3. Cryocooler and trap temperatures. Schematic of the trap housing (a) and illustration of temperatures over six cycles (b). The water trap $\left(T_{\text {water }}\right)$ is shown in blue, the enrichment trap ( $\left.T_{\text {enrichment }}\right)$ in red and the cryofocus trap $\left(T_{\text {cryo }}\right)$ in green.

uum isolated stainless steel device equipped with a mechanical overpressure valve and a rupture diaphragm (required for aircraft certification). Additionally, there is a pressuretight cylindrical double-wall tube insert built into the container, which widens into a cone at the top, establishing the $\mathrm{LN}_{2}$ reservoir from which the trap coolers are supplied (see Fig. 3).

In continuous operation, the inside pressure is maintained at $\sim 50$ mbar higher than the sampling system exhaust pressure $(\sim 1000 \mathrm{mbar})$ by the pressure-regulating system. The small overpressure drives the $\mathrm{LN}_{2}$ column up into the cone, where it evaporates at a rate proportional to the cone area immersed. In this way, the $\mathrm{LN}_{2}$ is evaporated directly below the traps, taking up the latent heat where it is actually needed, improving the efficiency of the system. With the filling valve open, the $\mathrm{LN}_{2}$ column remains at the $\mathrm{LN}_{2}$ level, which determines the idle $\mathrm{LN}_{2}$ consumption. By closing the filling valve, the mechanical pressure-regulating system stabilizes the system into a standby state. The level of $\mathrm{LN}_{2}$ in the container is determined with a capacitive $\mathrm{LN}_{2}$ level probe, which is connected through a custom-built voltage-frequency converter to the process controller. 


\subsubsection{Pressure regulation}

The main design objectives of the pressure-regulating system were (a) the establishment of constant sampling pressure independent of sample air flow or outside pressure (CPOR in Fig. 1) and (b) simple and robust control of the pressure inside the $\mathrm{LN}_{2}$ system even without electrical power supplied to the instrument (Press. Reg. in Fig. 1). Therefore, the system was built based on pneumatic components. Since no commercial components of reasonable weight and size were available, the diaphragm pressure controllers were custom built. The diaphragms were taken from 50 mbar commercial camping gas equipment and the housing of the pressure controller had to be rebuilt. By adapting the springs, the set points and dynamic ranges could easily be adapted to our needs.

The so-called constant-pressure output regulator (CPOR) is a custom-made part that has a $100 \mathrm{~cm}^{3}$ reference volume attached, which automatically resets to mean ambient pressure with a time constant of 1-2 days. It is used to keep the sampling system base pressure (which is also the $\mathrm{LN}_{2}$ container control reference pressure) approximately constant at a slightly higher level than ambient ( $\sim 50 \mathrm{mbar})$. This pressure is monitored through continuous measurement to correct for possible systematic effects on overall system performance. The main uncertainty here is pressure variation caused by temperature changes, which could lead to reference pressure changes in the field of the order of $10 \%$. For use in SOFIA on board a research aircraft, this volume had to be isolated from changes in aircraft internal pressure (ca. 120 mbar), whereas on ground or on ships it could be opened to remove drifts caused by temperature fluctuations.

Upstream of the CPOR a differential pressure regulator (indicated as Press. Reg. in Figs. 1, 4) of the same type was used to control both the $\mathrm{LN}_{2}$ level and the standby flow with the filling valves of the $\mathrm{LN}_{2}$ container closed. The filling level self-regulation operated analogously to the trap coolers. If the level in the $\mathrm{LN}_{2}$ container rises, the warmer part of the wall leads to enhanced evaporation, which immediately increases the pressure across the exhaust capillary, depressing the level again. The regulation of the $\mathrm{LN}_{2}$ level was very important in removing the feedbacks of the regulator action on the rest of the system.

\subsubsection{Trap temperature control}

Heating of the traps is achieved via direct current from a custom-built 4 V/30 A, 0-100\% DC/DC converter. The traps were electrically isolated with stainless steel fittings and Teflon ferrules. $1 / 16^{\prime \prime}$ tubing heating rates are $\sim 100^{\circ} \mathrm{C} \mathrm{s}^{-1}$ and hard to determine accurately because of the thermocouple reading delay. $1 / 8^{\prime \prime}$ (water trap) heating rates are $\sim 30^{\circ} \mathrm{C} \mathrm{s}^{-1}$.

Cooling of the traps is accomplished by controlling the flow rate of $\mathrm{N}_{2}$ downstream of the cooler housings by pro-

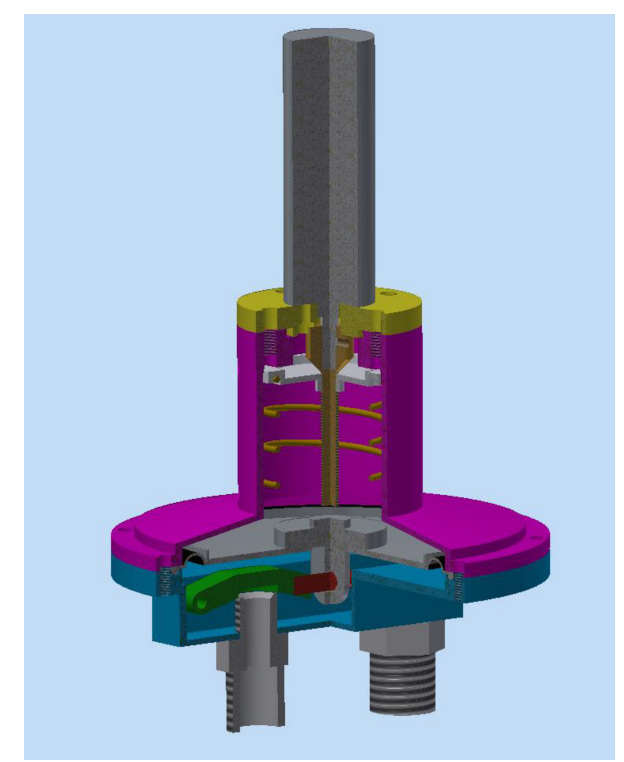

Figure 4. Pressure regulator of liquid nitrogen. The reference pressure volume is isolated by the purple aluminium cover. Gaseous $\mathrm{N}_{2}$ evaporates from LN2 dewar and enters the bottom right inlet. Once the pressure is higher than the reference, the membrane (placed between the blue and purple part) is regulated by the green spring and the nitrogen stream is directed to the exhaust (bottom left tube) releasing the pressure inside the LN2 container.

portional valves in series with $1 / 16^{\prime \prime}$ capillaries of appropriate length. The individual trap systems are self-stabilizing, because higher $\mathrm{LN}_{2}$ levels in each branch immediately lead to higher evaporation rates, and thus higher pressures forcing the $\mathrm{LN}_{2}$ column down again. With the current setup, cooling from +100 to a stable $-180^{\circ} \mathrm{C}$ is typically possible within $\sim 50 \mathrm{~s}$.

Depending on sample state, the process controller commands either the cooler valves or the trap tubes DC heater power to activate in order to maintain pre-set high or low temperatures. Typical temperature set points for water trap operation were between -40 and $+120^{\circ} \mathrm{C}$; the enrichment trap was run between -140 and $+120^{\circ} \mathrm{C}$ and the cryofocus trap between -160 and $+120^{\circ} \mathrm{C}$.

\subsection{Chromatographic oven}

The key factors in achieving the shortest possible cycle time of a fast GC system are (a) the reproducible heating and (b) extremely fast cooling to maximize the chromatogram run time while minimizing cycle time. To achieve these goals, the thermal masses of the oven, the column mandrel, the fan and the heater (Fig. 5) have to be minimized or eliminated. Furthermore, the surface-to-volume ratio of the mandrel has to be maximized and the insulation surface, mass and performance must be optimized. With the limited cooling power available for the GC oven, and to avoid condensation 


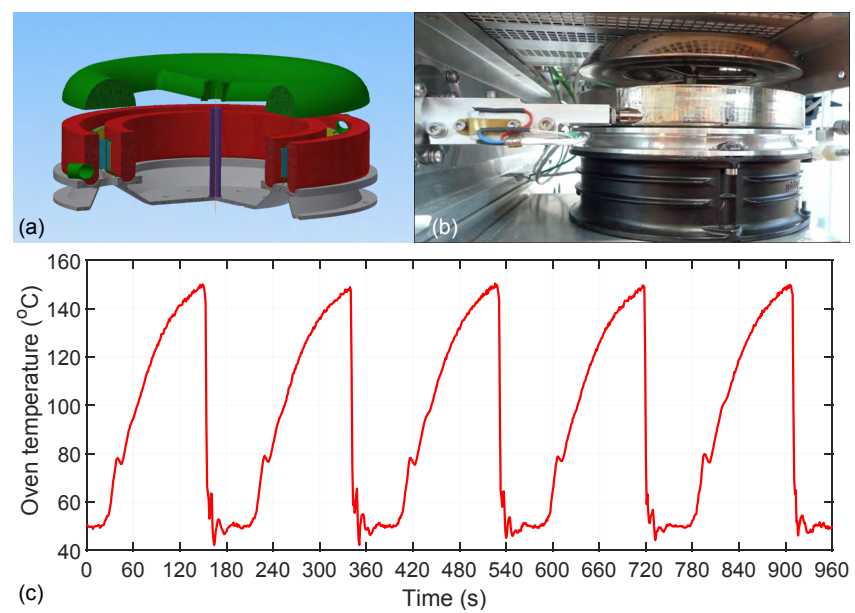

Figure 5. The chromatographic oven. Schematic design of the oven (a), photo of the oven during cooling (b) and illustration of the oven temperature from six consecutive cycles during the case study flight (c).

issues, the chromatography was run above ambient temperatures as the fan cannot create sub-ambient temperatures.

The oven was designed as a horizontally mounted toroidal structure (Fig. 5) to minimize internal surface area and thermal convection influence. The oven insulation is made of three double-walled hollow rings with wall thickness $\sim 20 \mu \mathrm{m}$, making up the inner, outer and top insulation. They were manufactured by galvanizing nickel onto a 3-D printed plastic core, which was dissolved afterwards by a solvent. Under this configuration the mass, heat capacity and heat conductivity were insignificant compared to convection and heat distribution.

The column mandrel $(130 \mathrm{~mm}$ OD) consists of thin wires holding two concentric sheath metal heaters $(0.1 \mathrm{~mm} \times 12 \mathrm{~mm}$ cross section) enveloping the column in shape. The column (DB-624, $10 \mathrm{~m}, 0.25 \mathrm{~mm}, 1.4 \mu \mathrm{m}$; Agilent Technologies) was nested between the heaters. A thermocouple was placed on the column to get a fast response measurement of the column temperature. The sheath heaters are directly heated with a $10 \mathrm{~V} / 10 \mathrm{~A}$ max, 0-100\% controllable custom built DC-DC converter.

The fan (EBM Papst, $56 \mathrm{~W}, \sim 200 \mathrm{~mm}$ OD) was taken out of the heated zone of the oven to remove its thermal mass. To sustain stirring of the air inside the oven and to minimize possible temperature gradients by strong thermal convection, the fan was mounted below the column, with $\sim 40 \%$ of the oven bottom area being open facing the fan blades.

For rapid cooling of the column, the oven top cover has to be opened in order to enable a high air flow rate through the ring gap around both sides of the mandrel (see Fig. 5b). During test experiments, it was found that the $\sim 50 \mathrm{~g}$ top cover could be lifted by the airstream of the fan, resettling down to the oven side wall rings when the fan was turned down. Since it is inherently difficult to control low heat capacity/high- power systems, the temperature regulator electronic parameters should be different at various temperatures to guarantee stability and minimize stabilization time. Our custom-built system is capable of controlling the system in real time. Lowtemperature settling time and stability were much improved by running the fan at low power along with the heater. Unfortunately, the fans implemented cannot run down to very low revolution rates to make a smooth fadeout of the fan possible, eliminating the minor disturbances on the temperature ramp (see Fig. 5c).

\subsection{Detector}

The GC column is connected to a quadrupole mass spectrometer MS (Agilent Technologies 5973) via a heated transfer line (143 mm deactivated column of $0.25 \mathrm{~mm}$; PN 1602255-10, Agilent Technologies). The pump of the MS was replaced by a high-power turbomolecular pump (EXT7DX, Edwards Vacuum) that can operate under higher gravitational forces to avoid problems during turbulence and on landing. The pre-pump was replaced with an oil-free membrane pump (MVP006-4, Pfeifer), to avoid potential contamination. In order to achieve higher peak resolution and therefore increase precision, the electronics board of the MS was exchanged with a fast, commercial version (Sideboard PCA G316965015, Agilent Technologies) and the MS is operated in selected ion mode (SIM), which substantially improves the detection limits while clearly separating the eluting peaks (Table 1). The dwell time for the individual ions selected was $10 \mathrm{~ms}$ and the chromatographic runtime was $2.4 \mathrm{~min}$ (Fig. 6). For the laboratory characterization the temperature of the oven was programmed to start at $60^{\circ} \mathrm{C}$, to be held for $20 \mathrm{~s}$, then ramp up to $70^{\circ} \mathrm{C}$ at a rate of $1.5^{\circ} \mathrm{C} \mathrm{min}^{-1}$ and then ramp up to $140^{\circ} \mathrm{C}$. A dwell time of $10 \mathrm{~ms}$ was selected as being the minimum dwell time for which the chromatographic peaks were well shaped. Tests have been conducted comparing 25 , 10 and $5 \mathrm{~ms}$. At $25 \mathrm{~ms}$, the peaks are not clearly shaped and hence larger uncertainties are induced during peak integration. Since with $5 \mathrm{~ms}$ dwell time the sensitivity of the detector's response was only slightly reduced $(\approx 5 \%)$, we recommend the use of $5 \mathrm{~ms}$ for future applications.

The linearity of the 5973MSD signal has been shown in multiple studies during the past decade (e.g. Yassaa et al., 2012). We observed a linear relationship for all species investigated $\left(R^{2}>0.9\right)$ for mixing ratios ranging from few $\mathrm{ppt}$ up to $3 \mathrm{ppb}$ (see Supplement Fig. S2). Average precision of the measurements ranges between 3.9 and $12.4 \%$ with the respective total uncertainties between 6.6 and $13.5 \%$ under laboratory conditions using a multicomponent (79 species) calibration standard with mixing ratios of about $50 \mathrm{ppb}$ (Apel-Riemer Environmental Inc.). The calibration standards used were within the manufacturers guaranteed accuracy period of 2 years. The detection limits were determined as 3 times the standard deviation of the signal produced by 
Table 1. Selective ion mode (SIM) was used to measure the listed compounds. The total uncertainty takes into account the measurement precision (derived as average of the three different concentration levels), the $5 \%$ uncertainty of the standard gas and the $2 \%$ uncertainty of the sampling volume. Retention times (RT) and their standard deviations from 2.4 min chromatograms are given in the last two columns. The values in parentheses indicate the performance during flight 20150813.

\begin{tabular}{|c|c|c|c|c|c|c|c|}
\hline Compound & Formula & $\begin{array}{r}\text { SIM } \\
\text { ion }\end{array}$ & $\begin{array}{l}\text { Detection } \\
\text { limit (ppt) }\end{array}$ & $\begin{array}{r}\text { Average precision } \\
\text { of measurements }(\%)\end{array}$ & $\begin{array}{r}\text { Total uncertainty } \\
(\%)\end{array}$ & $\begin{array}{r}\mathrm{RT} \\
(\mathrm{min})\end{array}$ & $\begin{array}{r}\text { RTSD } \\
(\min )\end{array}$ \\
\hline Methyl chloride & $\mathrm{CH}_{3} \mathrm{Cl}$ & 50,52 & $3(6)$ & $5.2(3.7)$ & $7.5(6.5)$ & 0.43 & 0.005 \\
\hline Methyl bromide & $\mathrm{CH}_{3} \mathrm{Br}$ & 94 & 1 & 5.2 & 7.5 & 0.52 & 0.008 \\
\hline Trichlorofluoromethane & $\mathrm{CCl}_{3} \mathrm{~F}$ & 101 & 1 & 5.4 & 7.6 & 0.61 & 0.02 \\
\hline Isoprene & $\mathrm{C}_{5} \mathrm{H}_{8}$ & 67 & $3(6)$ & $6.6(10.5)$ & $8.5(11.8)$ & 0.68 & 0.02 \\
\hline Propanal & $\mathrm{C}_{3} \mathrm{H}_{6} \mathrm{O}$ & 58 & $11(19)$ & $8.3(5.1)$ & $9.9(7.4)$ & 0.72 & 0.02 \\
\hline Ethane,1,1,2-trichloro-1,2,2-trifluoro & $\mathrm{C}_{2} \mathrm{Cl}_{3} \mathrm{~F}_{3}$ & 101 & 1 & 3.9 & 6.6 & 0.73 & 0.02 \\
\hline Acetone & $\mathrm{C}_{3} \mathrm{H}_{6} \mathrm{O}$ & 58 & $12(21)$ & $7.5(6.1)$ & $9.2(8.1)$ & 0.74 & 0,02 \\
\hline Methyl iodine & $\mathrm{CH}_{3} \mathrm{I}$ & 142 & 1 & 5.1 & 7.4 & 0.76 & 0,02 \\
\hline Carbon disulfide & $\mathrm{CS}_{2}$ & 76 & $1(4)$ & $5.3(11.6)$ & $7.6(12.8)$ & 0.78 & 0.02 \\
\hline Dichloromethane & $\mathrm{CH}_{2} \mathrm{Cl}_{2}$ & 49 & $3(9)$ & $5.4(11.3)$ & $7.6(12.5)$ & 0.84 & 0.02 \\
\hline Butanone & $\mathrm{C}_{4} \mathrm{H}_{8} \mathrm{O}$ & 43 & 10 & 7.4 & 9.2 & 1.02 & 0.02 \\
\hline Chloroform & $\mathrm{CHCl}_{3}$ & 83 & $1(4)$ & $6.1(10.4)$ & $8.1(11.7)$ & 1.06 & 0.03 \\
\hline 1,1,1-Trichloroethane & $\mathrm{C}_{2} \mathrm{H}_{3} \mathrm{Cl}_{3}$ & 97 & 1 & 6.5 & 8.4 & 1.46 & 0.05 \\
\hline Cyclohexane & $\mathrm{C}_{6} \mathrm{H}_{12}$ & 56 & 4 & 5.2 & 7.5 & 1.48 & 0.05 \\
\hline Carbon tetrachloride & $\mathrm{CCl}_{4}$ & 117 & $1(5)$ & $5.9(6.5)$ & $8(8.5)$ & 1.52 & 0.05 \\
\hline Benzene & $\mathrm{C}_{6} \mathrm{H}_{6}$ & 78 & $1(4)$ & $7.7(6.4)$ & $9.4(8.4)$ & 1.60 & 0.03 \\
\hline 1,2-Dichloroethane & $\mathrm{C}_{2} \mathrm{H}_{4} \mathrm{Cl}_{2}$ & 62 & 5 & 10.6 & 11.9 & 1.62 & 0.02 \\
\hline Trichloroethylene & $\mathrm{C}_{2} \mathrm{HCl}_{3}$ & 130 & 2 & 9.6 & 11.0 & 1.82 & 0.03 \\
\hline Toluene & $\mathrm{C}_{7} \mathrm{H}_{8}$ & 91 & $3(8)$ & $6.9(5.2)$ & $8.8(7.5)$ & 2.20 & 0.03 \\
\hline Tetrachloroethylene & $\mathrm{C}_{2} \mathrm{Cl}_{4}$ & 166 & $3(7)$ & $12.4(10.2)$ & $13.5(11.5)$ & 2.35 & 0.03 \\
\hline
\end{tabular}

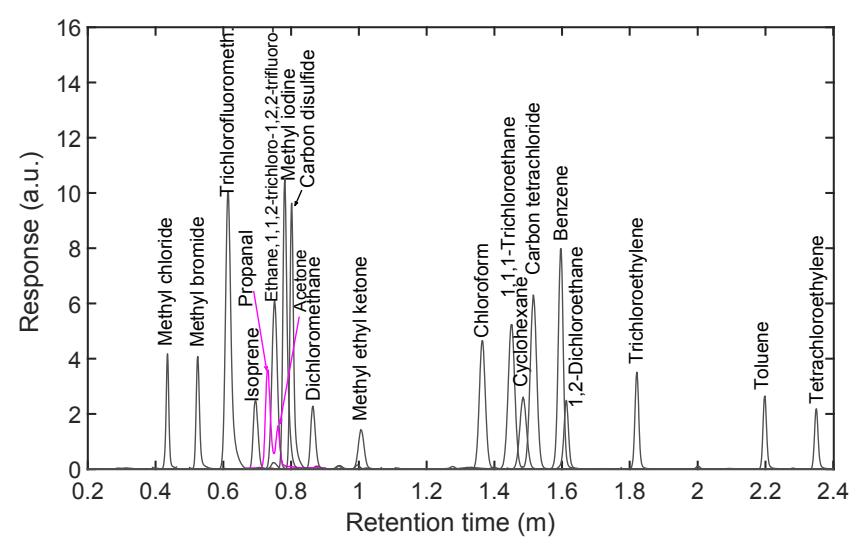

Figure 6. Chromatogram using standard gas. Elution times during a 3 min sample. The signals of propanal and acetone (purple) are illustrated as $10 \times$ the raw signals. The monitored compounds are listed in Table 1.

10 zero air samples in three different concentration levels (i.e. $\approx 125, \approx 250, \approx 500 \mathrm{ppt}$ ).

\subsection{Weight}

Any instrument that is mounted on a research aircraft is subject to weight limitations. Our system is comparatively compact and light $(120 \mathrm{~kg})$, despite the fact that is equipped with a liquid nitrogen container. The different cryogenic meth- ods and instrument configurations chosen for each fast GC (Table 2) are tailored to the specific research objectives of each instrument and come with both advantages and disadvantages concerning their application for measurements in the upper troposphere. The SOFIA instrument has been compactly built to meet the following specifications: to be able to fit on one aircraft rack $(65 \times 55 \times 163 \mathrm{~cm})$ at maximum $120 \mathrm{~kg}$, and operate for $17 \mathrm{~h}$ on liquid nitrogen, which enables even species such as methyl chloride to be effectively trapped in situ at an altitude range of $0-15 \mathrm{~km}$.

\subsection{Process controller hardware and software}

Due to limitations in the number of instrument operators on board a research aircraft, the system was designed to be fully automated. All electronic units and sequential sampling processes are controlled with electronics software that has been developed in-house (V25, MPIC). The V25 was additionally coupled with an external computer to trigger the MS data acquisition software Chemstation $^{\mathrm{TM}}$.

Faster GC-MS cycling and therefore a higher number of chromatograms acquired creates the need for robust peak integration software. While most of the peaks could be analysed with IAU-Chrom software (Sala et al., 2014), great attention has been given to the separation of peaks that elute in very close retention times and are not clearly separated. Therefore, additional effort was put into the development of software that could clearly separate co-eluting peaks. MPIC- 
Table 2. Custom-built fast GC instruments for on-line monitoring of organic trace gases. Non-reported information is denoted with n.r.

\begin{tabular}{|c|c|c|c|c|c|c|c|c|}
\hline Instrument & Detector & Cryogenic method & $\begin{array}{r}\text { Time resolution } \\
\text { (min) }\end{array}$ & $\begin{array}{l}\text { Adsorption } \\
\text { temp. }\left({ }^{\circ} \mathrm{C}\right)\end{array}$ & $\begin{array}{r}\text { Lowest } \\
\text { DL (ppt) }\end{array}$ & $\begin{array}{r}\text { Highest } \\
\text { precision }(\%)\end{array}$ & $\begin{array}{r}\text { Weight } \\
(\mathrm{kg})\end{array}$ & Reference \\
\hline SOFIA & MSD 5973 & $\mathrm{LN}_{2}$ & $3(2)$ & -160 & 1 & 4 & 120 & This study \\
\hline TOGA & MSD 5973 & $\mathrm{LN}_{2}$ & 2 & -120 & 1 & 3 & $<200$ & $\begin{array}{l}\text { Apel and UCAR/NCAR } \\
\text { - Earth Observing } \\
\text { Laboratory (2016) }\end{array}$ \\
\hline GhostMS & MSD 5975 & Stirling cooler & 4.3 & -100 & 0.001 & 2 & n.r. & Sala et al. (2014) \\
\hline $\mathrm{HGC}$ & MSD 5975 & compressed refrigerant & 9 & 30 & 1 & $<1$ & 128 & Jäger (2014) \\
\hline$\mu$ Dirac & ECD & n.r. & $8-15$ & $15-25$ & 0.5 & 1 & 11 & Gostlow et al. (2010) \\
\hline
\end{tabular}

Chrom, a new peak integration software written in IGOR, was used for the separation of acetone and propanal peaks.

\subsection{Laboratory characterization}

\subsubsection{Water vapour}

The purpose of the water trap is to retain the atmospheric water vapour, which is known to induce chromatographic artefacts, degrade chromatographic separations and over time damage the column, degrade chromatographic separations and over time damage the column. It was found that large sampling flows result in poor water trapping and therefore poor reproducibility of the sampled analytes. Small flows $(<40 \mathrm{sccm})$ can sufficiently remove atmospheric water vapour with up to $100 \%$ relative humidity $(\mathrm{RH})$. Supplement Fig. S2 illustrates calibration points that were obtained with both dry $(0 \% \mathrm{RH})$ and wet $(100 \% \mathrm{RH})$ air used to dilute the calibration mixture internally. To demonstrate stability of the system under changing conditions each calibration step was performed with dry and sequential wet calibrations. The detection efficiency and reproducibility of all calibration curves indicates that the water trap effectively removes water vapour during sampling.

\subsubsection{Ozone}

Problems from co-collection of ozone have been recognized previously (Goldan et al., 1995) and are documented in several studies (Bates et al., 2000; Plass-Dülmer et al., 2002; Pollmann et al., 2005; Lee et al., 2006; Apel et al., 2008; Arnts, 2008; Hellen et al., 2012). The ozone interference can be either positive via artefact formation from reaction with ozone in the sampling system (e.g. OVOCs) or negative via the loss of analytes during the enrichment stage from oxidation by ozone. The positive effect was investigated by sampling VOC-free air from an ozone generator (Thermo Environmental Inc., 49 $\mathrm{C} \mathrm{O}_{3}$ generator, USA) under increasing ozone mixing ratios $(0-200 \mathrm{ppb})$. Even with the highest $\mathrm{O}_{3}$ mixing ratios tested, we did not observe any artefact formation for our system.

To investigate the loss of analytes from oxidation by ozone, the air produced by the ozone generator was exter- nally mixed with the multicomponent calibration gas standard, achieving a mixing ratio of about $0.5 \mathrm{ppb}$ for the investigated species. During the OMO campaign about $99 \%$ of the ambient ozone measurements were below $100 \mathrm{ppb}$ and the maximum recorded value was $114 \mathrm{ppb}$. Hence, we have conducted experiments up to $150 \mathrm{ppb}$ of $\mathrm{O}_{3}$. Fig. 7 illustrates the percentage difference (blue circles) from the reference value obtained at $0 \mathrm{ppb}$ of $\mathrm{O}_{3}$. No artefacts were observed for all species up to $75 \mathrm{ppb}$ of $\mathrm{O}_{3}$. However, for $\mathrm{O}_{3}$ mixing ratios higher than $75 \mathrm{ppb}$, the double-bonded species (i.e. isoprene, CFC-113, trichloroethylene and tetrachloroethylene) were reduced as a result of ozonolysis. The maximum loss was observed for trichloroethylene at $150 \mathrm{ppb} \mathrm{O}_{3}(\approx 20 \%$ of the reference value). In contrast with the oxidized species, acetone and propanal were increased for $\mathrm{O}_{3}$ mixing ratios higher than $75 \mathrm{ppb}$. This increase can be attributed to production by ozone reactions occurring with other species that are present in the multicomponent gas standard, as the supply of ozone enriched zero air did not result in production of OVOCs.

To better address the observed ozone artefacts, an ozone scrubber (sodium thiosulfate $\left(\mathrm{Na}_{2} \mathrm{~S}_{2} \mathrm{O}_{3}\right)$ implemented quartz filter; $47 \mathrm{~mm}$, Whatman, UK) was installed at the inlet. Prior to the experiments, the ozone scrubber was tested for artefacts by comparing the response of about $0.5 \mathrm{ppb}$ of calibration gas mixture with and without the ozone scrubber. Since no artefacts were observed, the same experiment was performed with the ozone scrubber in line. As demonstrated in Fig. 7 (red squares), all the investigated species displayed a similar response independent of the ozone mixing ratios. Therefore, we conclude that the use of an ozone scrubber is essential for the accurate determination of analytes under high ozone mixing ratios $\left(\geq 100 \mathrm{ppb}\right.$ of $\mathrm{O}_{3}$ ).

\subsection{Specifications during OMO campaign}

The system was installed on board the HALO aircraft after its final configuration and certification. At first, a limited number of compounds (11) was monitored in order to ensure reliable quantification (Table 1). At the start of the OMO campaign, high sampling flows $(100 \mathrm{sccm})$ resulted in inefficient water removal and hence poor and non-reproducible chromatographic peaks. The solution was to operate the sys- 

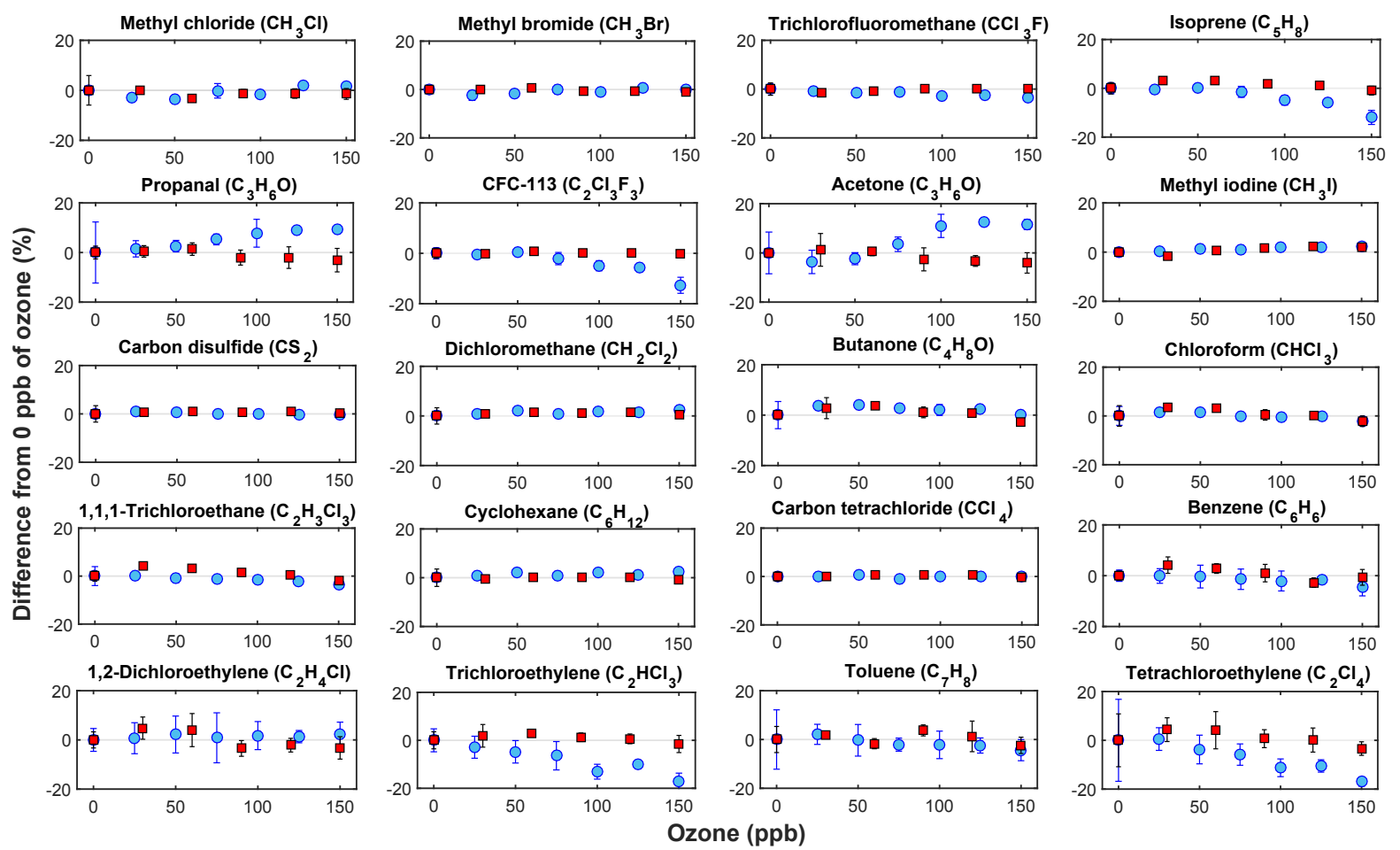

Figure 7. Ozone experiments. A stable VOC mixing ratio $(\approx 0.5 \mathrm{ppb})$ was sampled under $0-150 \mathrm{ppb}$ of $\mathrm{O}_{3}$ with (red squares) and without (cyan circles) the use of ozone scrubber.

tem with a lower sampling flow $(40 \mathrm{sccm})$ and only at high altitudes where low dew point temperatures do not affect the sampling procedure. Post-campaign tests (see Sect. 2.7) showed that under such small sampling flows the water trap sufficiently retain water vapour and therefore the instrument can be operated even under ground conditions. The sampling time was $1 \mathrm{~min}$ so a total volume of $40 \pm 6 \mathrm{~mL}$ was collected into the traps. During sample collection, the water trap temperature was set to $-30 \pm 0.3^{\circ} \mathrm{C}$ and the enrichment trap temperature to $-140 \pm 4^{\circ} \mathrm{C}$. During the sample transfer, the cryofocus trap temperature was set to $-160 \pm 1^{\circ} \mathrm{C}$. All traps were then heated to $120^{\circ} \mathrm{C}$ to ensure that all volatiles were desorbed efficiently from each trap.

Prior to each flight, a pre-flight protocol was followed. The instrument was turned on (power consumption $\approx 1000 \mathrm{~W}$ ) and all gas cylinders were opened. During the filling of $\mathrm{LN}_{2}$ container $(\approx 10 \mathrm{~min})$, the traps valve was set to INJECT position (see Fig. S1) and the flow controller was set to zero. This allows evacuation of any residual air in the lines and inspection of major leaks by monitoring the minimum pressure inside the MS. Subsequently, the MS heaters were turned on and the traps and $\mathrm{GC}$ column were heated to $100^{\circ} \mathrm{C}$ for about half an hour, even if the MS and the heaters can reach desired temperature in less than $10 \mathrm{~min}$. Once the aircraft was outside the hangar, the mass spectrometer was tuned and inspected for any water and air residuals in the MS. The minimum start-up time required is as low as $30 \mathrm{~min}$ but usually a full hour was required in order to produce reliable chromatograms, clean blanks and stable calibrations. When it had been assured that there were no leaks in the system, a multipoint calibration was performed and the mission sequence was set. A common strategy was to perform three calibration steps (stable mixing ratio of about $100 \mathrm{ppt}$ ) or three zero air measurements after 20 consecutive ambient samples. The sequence was stopped above sampling-restricted areas and calibrations with dry $\mathrm{N}_{2}$ compressed gas were performed. In addition, the sequence was reset in calibration mode whenever the flying altitude was changed. Upon landing and given the time restrictions that are usually present, a calibration check was performed and the MS was vented $(\approx 40 \mathrm{~min})$ until the power supply from the aircraft was terminated.

The GC oven temperature was programmed to start at $50^{\circ} \mathrm{C}$, held for $20 \mathrm{~s}$, then ramped up to $80^{\circ} \mathrm{C}$ at $2^{\circ} \mathrm{C} \mathrm{s}^{-1}$ and then ramped up to $150^{\circ} \mathrm{C}$ at a rate of $1^{\circ} \mathrm{C} \mathrm{s}^{-1}$ (Fig. 5). An ambient chromatogram with these settings is shown in Supplement Fig. S3. Under the initial configuration of the GC oven, imperfect reproducibility of the temperature ramp resulted in small retention time shifts that nonetheless remained within the selected SIM time windows. Postcampaign improvements of the oven ventilation control system and method (i.e. improved oven stability by running the fan below its commercial speed, and increased initial oven temperature of $60^{\circ} \mathrm{C}$ ) resulted in more reproducible temperature profiles, largely eliminating the retention time shifts. In 
the first flight campaign a sample was acquired every $3.1 \mathrm{~min}$ with an MS run of $2.4 \mathrm{~min}$. In order to assess possible pressure dependences, calibrations were performed at each pressure level during each flight. During flight, higher uncertainty values were determined as a result of higher precision error (Table 1).

\section{Case study of Asian monsoon outflow}

\subsection{Flight 20150813}

The scientific aim of the OMO campaign was to investigate the oxidation processes in the convectively lifted air masses that originate in polluted areas of South Asia, and are then transported within the Indian monsoon anticyclonic flow system in the upper troposphere. The base of operation in the eastern Mediterranean was Paphos airport, in Cyprus, and flights generally headed east over the Arabian Peninsula to intercept monsoon flows heading west. Methane, measured by IR absorption spectroscopy (Schiller et al., 2008; Tadic et al., 2017), was used to identify monsoon outflowinfluenced air masses. A threshold methane value was derived to identify such plumes based on the average of profiles (4-10 km height; 12 flights) over Cyprus, Italy and Germany, which represented the European background without monsoon influence. The threshold was calculated as the sum of the averaged observations plus 2 times the standard deviation (threshold $=$ average $+2 \times \sigma=1879.8 \mathrm{ppb}$ ). Methane mixing ratios above this threshold were assumed to be influenced by the Indian summer monsoon system.

On 13 August 2015, a flight was performed to traverse the anticyclonic system that was forecast to extend over the eastern part of the Arabian Peninsula at high altitudes (see Fig. 8). The results from this flight will be used as a case study in order to demonstrate the instrument performance.

\subsection{Pollution plume characteristics}

According to the aforementioned $\mathrm{CH}_{4}$ threshold, monsooninfluenced air masses were mainly encountered on the eastern part of the flight track, with a few additional areas located above continental Saudi Arabia. On average, $\mathrm{CH}_{4}$ increased by $66.2 \pm 23.2 \mathrm{ppb}$ and CO by $29.5 \pm 12.3 \mathrm{ppb}$ in the pollution plumes (see red dots in Fig. 9a). On the return flight, very clean air masses were encountered and these mixing ratios were considered as background (12:30-13:30 UTC). We define the excess mixing ratios (ExMR) as the difference between the observations obtained under background conditions (bg) and the respective mixing ratios measured within the pollution plume (Yokelson et al., 2013).

Increased mixing ratios of all hydro- and chlorocarbons were observed in the pollution plume except for carbon tetrachloride $\left(\mathrm{CCl}_{4}\right)$, which remained constant during the entire flight $\left(\left[\mathrm{CCl}_{4}\right]_{\mathrm{BG}}=124 \pm 13 \mathrm{ppt}\right.$, $\left.\left[\mathrm{CCl}_{4}\right]_{\text {plume }}=123 \pm 14 \mathrm{ppt}\right)$. The largest increases were

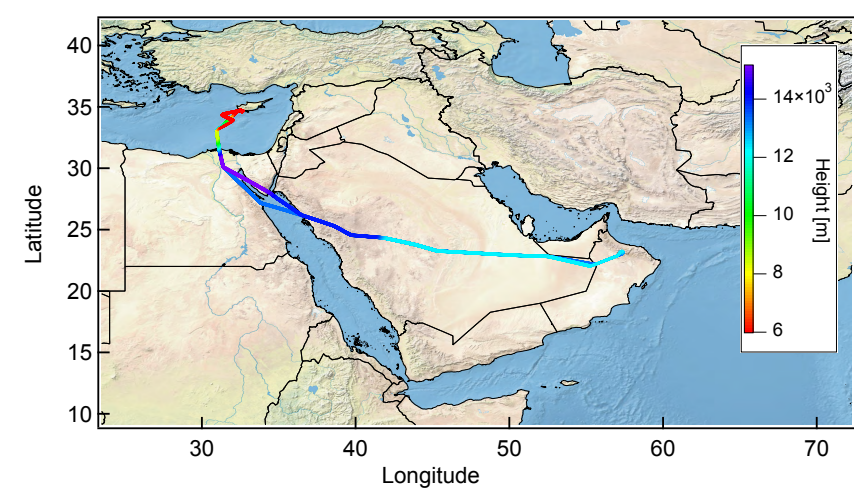

Figure 8. Route of research flight 20150813.

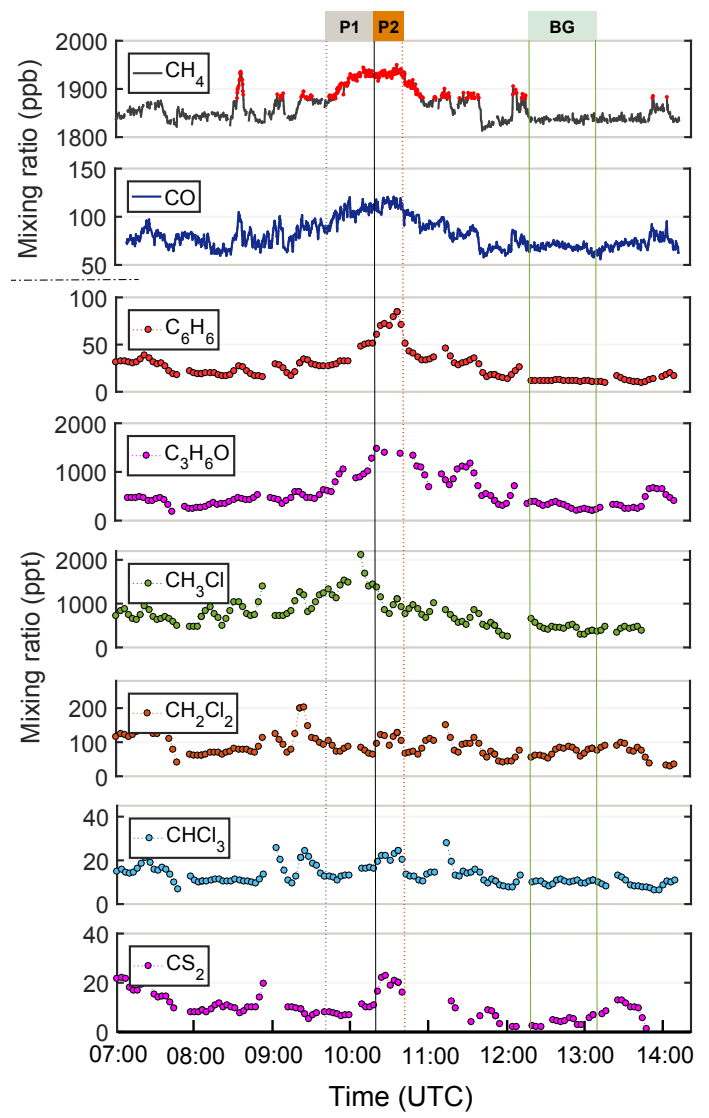

Figure 9. Time series of eight compounds from flight 20150813.

observed for benzene $\left(\right.$ ExMR $\left._{\mathrm{C}_{6} \mathrm{H}_{6}}=269 \%\right)$ and acetone $\left(\right.$ ExMR $\left._{\mathrm{C}_{3} \mathrm{H}_{6} \mathrm{O}}=225 \%\right)$ while strong increases were also observed for chloromethane $\left(\mathrm{ExMR}_{\mathrm{CH}_{3} \mathrm{Cl}}=140 \%\right)$ and chloroform $\left(\mathrm{ExMR}_{\mathrm{CHCl}_{3}}=55 \%\right)$. Dichloromethane mixing ratios were higher by $18 \%$ on average in the pollution plumes. However, this falls within the uncertainty range of the measurement on this flight. Besides the hydro- and chlorocarbons, carbon disulfide was more than twice as high in the 
plume (ExMR $\left.\mathrm{CS}_{2}=109 \%\right)$ with a maximum measured mixing ratio of $23 \mathrm{ppt}$.

The highest correlation coefficient between the commonly used pollution marker $\mathrm{CO}$ and the monitored hydrocarbons was observed for benzene $\left(\mathrm{CC}_{\mathrm{CO}, \mathrm{C}_{6} \mathrm{H}_{6}}=0.85\right)$ and acetone

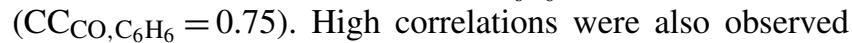

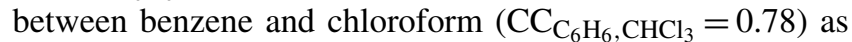

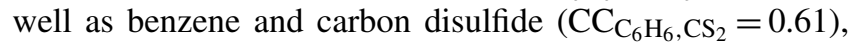
and even higher for the air masses marked as pollution

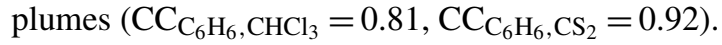

\subsection{Air mass separation}

The highest mixing ratios of $\mathrm{CH}_{4}$ and $\mathrm{CO}$ were observed between 09:53 and 10:40 UTC over Oman (Figs. 9 and 12) and with relatively stable plume delineator abundance $\left(\left[\mathrm{CH}_{4}\right]=1925 \pm 14 \mathrm{ppb} ;[\mathrm{CO}]=109 \pm 7 \mathrm{ppb}\right)$, which is indicative of a large-scale pollution plume. Interestingly, the main species measured by SOFIA reveal markedly different mixing ratios for the first and second part of the plume. This suggests that, what appears to be one plume in the relatively unspecific marker compounds $\left(\mathrm{CO}\right.$ and $\left.\mathrm{CH}_{4}\right)$, has two distinctly different composition regions when volatile organic compounds are considered. To investigate the chemical differences between these air masses, the plume was subdivided into two separate plumes termed as P1 and P2.

In Fig. 10 we illustrate the ExMRs of the main VOC species measured over $\mathrm{P} 1$ and $\mathrm{P} 2$ against the respective ExMR of $\mathrm{CH}_{4}$ and $\mathrm{CO}$. Benzene, acetone and chloroform increased in both plumes, moderately correlated with the respective increase in the $\mathrm{CO}$ mixing ratios $\left(R_{\mathrm{C}_{6} \mathrm{H}_{6}, \mathrm{CO}}^{2}=0.6\right.$, $R_{\mathrm{C}_{3} \mathrm{H}_{6} \mathrm{O}, \mathrm{CO}}^{2}=0.61, R_{\mathrm{CHCl}_{3}, \mathrm{CO}}^{2}=0.52$ ).

Benzene is the most abundant aromatic hydrocarbon in the atmosphere (Martín-Reviejo and Wirtz, 2005) and its gas phase chemistry is dominated by the reaction with $\mathrm{OH}$ radical (Bloss et al., 2005). Differences between biomass burning and pollution outflow can be traced by the benzene/ $\mathrm{CO}$ ratio. Scheeren et al. (2003) reported a ratio of $0.23 \mathrm{ppt} \mathrm{ppb}^{-1}$ inside the monsoon outflow while Andreae and Merlet (2001) derived a ratio of $1.3 \mathrm{ppt} \mathrm{ppb}^{-1}$ for biomass-burning plumes. In our measurements, the benzene / $\mathrm{CO}$ ratio was significantly increased in $\mathrm{P} 2\left(\mathrm{Benz} / \mathrm{CO}_{\mathrm{P} 1}=0.4 \mathrm{ppt} \mathrm{ppb}^{-1}\right.$,

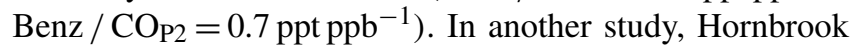
et al. (2011) used the excess ratios $(\Delta \mathrm{Benz} / \Delta \mathrm{CO})$ for all biomass-burning influenced air masses and reported values that range between 0.5 and $2.5 \mathrm{ppt} \mathrm{ppb}^{-1}$. The respective values were increased by $\sim 80 \%$ in P2 (compared with P1), with an average ratio of $1.44 \pm 0.19 \mathrm{ppt} \mathrm{ppb}^{-1}$, indicating the influence of biomass-burning emissions in the second part of the plume.

Acetone is the most abundant OVOC in the upper troposphere with mixing ratios that can reach $2 \mathrm{ppb}$ (Pöschl et al., 2001), with strong seasonal variations at the mid-latitude tropopause (Sprung and Zahn, 2010). It has both anthro-

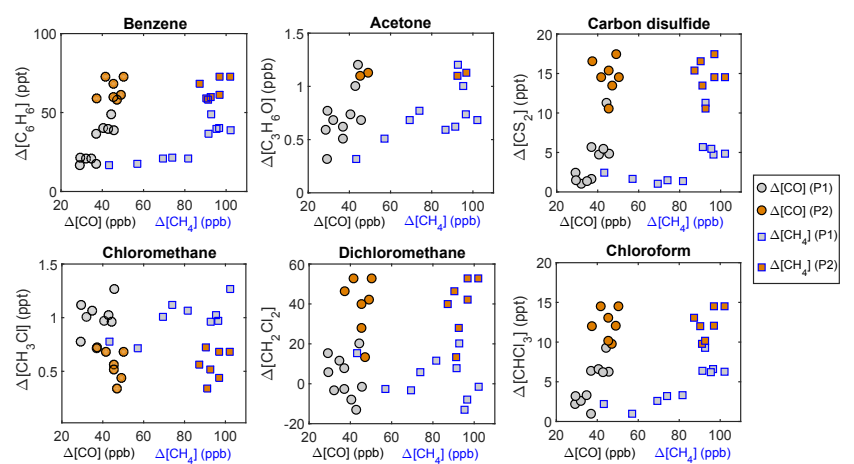

Figure 10. Enhancement mixing ratio correlations in the two plumes. Correlations of ExMR between $\mathrm{CO}$ (cycles) and $\mathrm{CH}_{4}$ (squares) with benzene, acetone, carbon disulfide, chloromethane, dichloromethane and chloroform.

pogenic and biogenic sources (Jacob et al., 2002; Khan et al., 2015) but it can be also formed by the oxidation of precursor compounds such as propane (Jacob et al., 2002; Fischer et al., 2012). Biomass burning is another direct source of acetone (Holzinger et al., 2005). We have observed values up to $1.5 \mathrm{ppb}$ in the Asian monsoon plume with highly elevated mixing ratios in $\mathrm{P} 2\left(\left[\mathrm{C}_{3} \mathrm{H}_{6} \mathrm{O}\right]_{\mathrm{P} 1}=995 \pm 246 \mathrm{ppt}\right.$, $\left[\mathrm{C}_{3} \mathrm{H}_{6} \mathrm{O}\right]_{\mathrm{P} 2}=1397 \pm 18 \mathrm{ppt}$ ), identified as biomass-burning influence. At the same time, propanal was moderately increased from $19 \pm 4 \mathrm{ppt}$ in $\mathrm{P} 1$ to $29 \pm 5 \mathrm{ppt}$ in P2. In a recent study, Fischbeck et al. (2017) showed that the increase of acetone in such pollution plumes is more likely to depend on the initial mixing ratios at the source rather than on secondary production.

Chloroform has both anthropogenic and biogenic sources, while biomass burning is considered to be an important contributor (Laturnus et al., 2002). We observed an increase of chloroform in $\mathrm{P} 1\left(\left[\mathrm{CHCl}_{3}\right]_{\mathrm{P} 1}=15 \pm 3 \mathrm{ppt}\right)$ and a stronger increase in $\mathrm{P} 2\left(\left[\mathrm{CHCl}_{3}\right]_{\mathrm{P} 2}=22.4 \pm 2 \mathrm{ppt}\right)$ compared to the background measurements $\left(\left[\mathrm{CHCl}_{3}\right]_{\mathrm{BG}}=10 \pm 1 \mathrm{ppt}\right)$. In general, chloroform increased in a linear relationship with benzene.

For most species we observed enhanced mixing ratios in the second part of the plume (P2). The only compound that displayed a different tendency is chloromethane, which was higher in $\mathrm{P} 1$ compared to $\mathrm{P} 2\left(\left[\mathrm{CH}_{3} \mathrm{Cl}\right]_{\mathrm{P} 1}=1485 \pm 274 \mathrm{ppt}\right.$, $\left[\mathrm{CH}_{3} \mathrm{Cl}\right]_{\mathrm{P} 2}=988 \pm 136 \mathrm{ppt}$ ). While biomass burning is also a significant source of chloromethane (Rudolph et al., 1995; Andreae and Merlet, 2001; Keppler et al., 2005; Umezawa et al., 2014), we identified stronger emissions from the non-burning monsoon outflow, which indicates that different strong sources are present. Scheeren et al. (2003) have shown that a ratio of $10 \mathrm{pptppb}^{-1}$ is indicative of Asian pollution over the eastern Mediterranean. Hence the higher $\mathrm{CH}_{3} \mathrm{Cl} / \mathrm{CO}$ ratios observed in $\mathrm{P} 1\left(\left[\mathrm{CH}_{3} \mathrm{Cl} / \mathrm{CO}\right]_{\mathrm{P} 1}=14.1 \pm 2.6 \mathrm{ppt} \mathrm{ppb}^{-1}\right)$ compared with $\mathrm{P} 2\left(\left[\mathrm{CH}_{3} \mathrm{Cl} / \mathrm{CO}\right]_{\mathrm{P} 2}=8.7 \pm 1.5 \mathrm{ppt} \mathrm{ppb}^{-1}\right)$ are indicative of 
pollution outflow, which may have been influenced by other strong sources such as tropical vegetation (Gebhardt et al., 2008), biofuel use (Lobert et al., 1999) or the burning of agricultural residues, waste and dung (Scheeren et al., 2002).

To further investigate the air mass characteristics, normalized excess mixing ratios (NERMs) relative to $\mathrm{CO}$, were calculated and are presented in Fig. 11. The observed NERMs between benzene and chloromethane reveal a distinct separation of the relationships between the two parts of the plume. The linear relationship for chloromethane inside $\mathrm{P} 2$ $\left(R^{2}=0.74\right)$, in combination with the range of $\mathrm{CH}_{3} \mathrm{Cl} / \mathrm{CO}$ ratios (6.7 to $10.9 \mathrm{ppt} \mathrm{ppb}^{-1}$ ), supports the assumption that the air was influenced by biomass burning (Scheeren et al., 2003). The NERMs of chloroform and carbon disulfide increased in a similar linear manner. In particular, chloroform enhancement ratios, relative to $\mathrm{CO}$, were uniquely correlated with the respective enhancement of benzene $\left(R^{2}=0.98\right.$; Fig. 10).

We further examine the distinct plume characteristics by calculating 10-day back-trajectories using the FLEXible PARTicle dispersion model (FLEXPART; Stohl et al., 1998). As shown in Fig. 12, when HALO descended by $1 \mathrm{~km}$ at 10:21 UTC, a different air mass was measured. P1 originated over north India and at higher altitudes $(\sim 8 \mathrm{~km})$ and was transported within the prevailing anticyclonic system. In contrast, the air mass $\mathrm{P} 2$ emerged from lower altitudes over central India with some influence from Bangladesh, Bhutan and west Myanmar, where biomass burning (Streets et al., 2003; van der Werf et al., 2006) and fuel consumption (van der Werf et al., 2010) are more prominent.

\section{Discussion}

The need for high time resolution monitoring in the upper troposphere has given rise to a new generation of custommade, fast GC instruments that were designed to operate on board research aircraft (Table 2). The most critical parameter for fast GC instrumentation on board a research aircraft is time resolution. As demonstrated in the case study section, the aircraft can rapidly cross air masses with different characteristics, and high-resolution monitoring is essential to interpret the underlying atmospheric phenomena.

The main constraints in achieving high time resolution sampling for GC-MS systems are the cooling and heating rates of the traps and GC oven, together with the inherent limitations of chromatographic separation time. During the first campaign (OMO), our system was operated with a time resolution of $3.1 \mathrm{~min}$, while a reduction to $2 \mathrm{~min}$ is feasible due to the high cooling rates of both the GC oven and traps' housing. Stable and reproducible temperature are essential in to ensure reproducible retention times that ease the analysis.

Quadrupole MS has been the preferred method for quantitative detection despite the inherent restrictions on the number of species monitored due to limits in the number of mea-
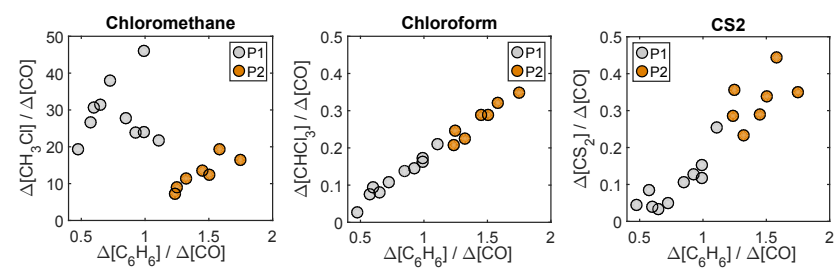

Figure 11. Comparison plots of NEMRs to CO for chloromethane, chloroform and carbon disulfide. The first part of the pollution plume P1 is indicated by grey bullets and the second part P2 with orange bullets.

surement points needed to accurately define the fast eluting peaks and the numbers of ions that can be sequentially monitored. In the selected ion monitoring mode (SIM) several quadrupole systems have proven to be sufficiently sensitive and robust, with good reproducibility and a high degree of linearity over a wide range of mixing ratios (e.g. Apel et al., 2003). Importantly, when targeting fast measurement times, the MS allows the separation of co-eluting substances that can be distinguished by their different mass and fragmentation patterns. While considerable improvements on the mass resolving power and speed could be achieved with a time-offlight mass spectrometer (TOF-MS) that can simultaneously measure all mass-to-charge signals at high frequency, detector non-linearities of the instrument sensitivity have been observed (Hoker et al., 2015; Obersteiner et al., 2016a).

Generally, for all systems, prior to detection, the substances of interest are pre-concentrated in an enrichment trap, where low temperatures are used to retain them. The range of trapping temperatures required is highly dependent on the target substances. SOFIA utilizes $\mathrm{LN}_{2}$ in order to achieve large cooling capacity allowing high-vapour-pressure VOCs such as methyl chloride to be trapped without the need of an absorbent material that may induce artifacts and memory effects (Apel et al., 2003). The main disadvantage of using $\mathrm{LN}_{2}$ as cryogen is the significant volumes required in combination with safety restrictions and supply in remote locations. The SOFIA system can be used on routine flights that do not exceed $17 \mathrm{~h}$. However, multiple flights that include an extended layover or remote site landing for an overnight stay will restrict the operation of SOFIA to the outward flight, unless a re-supply of $\mathrm{LN}_{2}$ is available in the host airport.

Alternative cryogen-free approaches have also been realized. Compression coolers containing refrigerant (e.g. 1,1,1,2-tetrafluoroethane) in combination with a tube evaporator that cools a liquid such as $50 \%$ ethanol have been applied (Jäger, 2014). The disadvantage of this method is the reduced cooling capacity with associated limitations in retaining high-vapour-pressure substances. A further solution has been the use of Stirling coolers, as demonstrated by Obersteiner et al. (2016b) and Lerner et al. (2017). These only require electrical power and hence are eminently suitable for long-term use at remote locations. The cooling rates and min- 

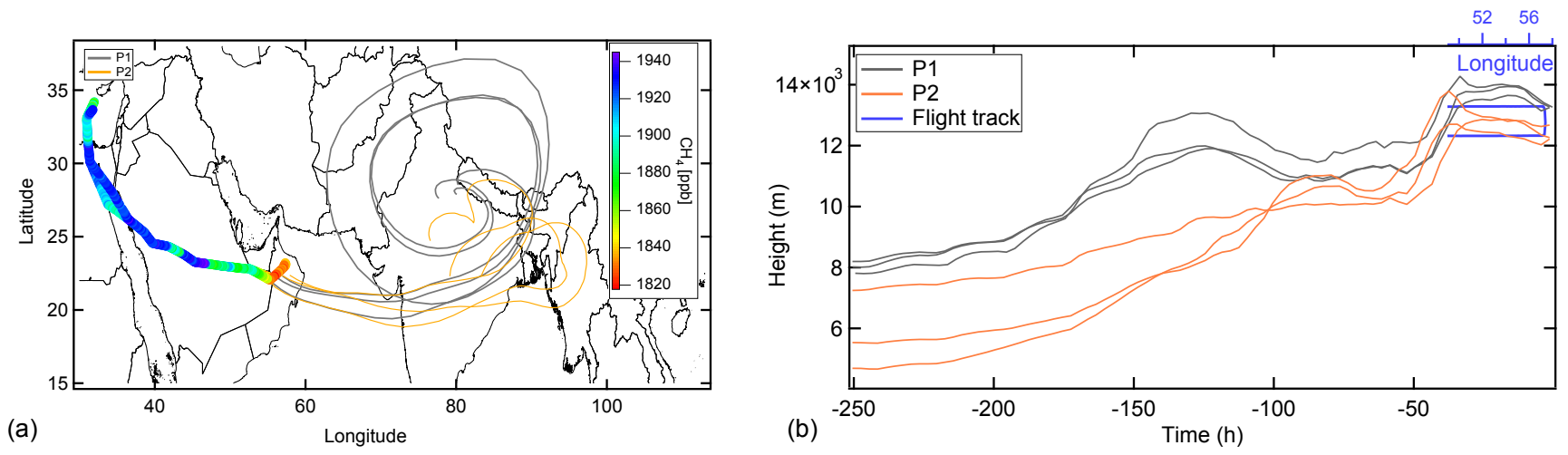

Figure 12. Back-trajectories for the plumes $\mathrm{P} 1$ and $\mathrm{P} 2$ according to geographic location (a) and in time (b).

imum attainable temperatures are comparable (albeit slightly higher) with the $\mathrm{LN}_{2}$ systems, even if they are not as powerful. In any case, low adsorption temperatures will result in trapping $\mathrm{CO}_{2}$, which can induce chromatographic and detection problems depending on the selected ions monitored. In our system the most abundant atmospheric gases (nitrogen, oxygen, argon) will not be concentrated in the sample, but the less volatile gases such as $\mathrm{CO}_{2}$ are trapped. The elution of $\mathrm{CO}_{2}$ restricts the range of the analytes that can be monitored (e.g. acetaldehyde). Nonetheless, the selected species that are implemented in our method do not have interferences with the $\mathrm{CO}_{2}$ ions and hence our measurements were not influenced by ambient $\mathrm{CO}_{2}$.

\section{Conclusions}

We have developed a new fast GC-MS instrument for airborne measurements of volatile organic compounds including hydro- and halocarbons, OVOC and sulfur species. The system incorporates a novel cryogen-conservative VOC enrichment system that is based on the differential pressure between a $\mathrm{LN}_{2}$ dewar and the trap housing to transport the cryogen as a liquid, and rapidly cool the traps to the desired temperatures. In addition, we have developed a new chromatographic oven with exceptionally high cooling rates $\left(30^{\circ} \mathrm{C} \mathrm{min}^{-1}\right)$ and rapid stabilization, which helps achieve relatively high measurement time resolution. SOFIA was operated on-board the HALO research aircraft during the OMO campaign to study the convectively transported pollutants within the Indian monsoon anticyclone system. The high time resolution allowed the investigation of a seemingly uniform pollution plume and the distinguishing of two notably different air masses. We have confirmed the distinct origins of these air masses with the use of a back-trajectory transport model, and conclude that the use of on-line, high-resolution monitoring is essential for the adequate characterization of air masses and atmospheric processes that take place in the upper troposphere.
Data availability. Details about the campaign can be found at http: //www.halo.dlr.de/science/missions/omo/omo.html, where data can be downloaded upon request.

\section{The Supplement related to this article is available online at https://doi.org/10.5194/amt-10-5089-2017-supplement.}

Competing interests. The authors declare that they have no conflict of interest.

Acknowledgements. We would like to thank all participants of the OMO campaign, the German Aerospace Centre (DLR), Enviscope $\mathrm{GmbH}$ and EDT Offshore Ltd for excellent cooperation during the field campaign. In particular, we thank Rolf Maser, Marcel Dorf and Kyriakos Michael for their generous support at Paphos airport in Cyprus. We thank Eric C. Apel and Aaron Johnson for helpful discussions during the preliminary design phase.

The article processing charges for this open-access publication were covered by the Max Planck Society.

Edited by: Eric C. Apel

Reviewed by: four anonymous referees

\section{References}

Andreae, M. O. and Merlet, P.: Emission of trace gases and aerosols from biomass burning, Global Biogeochem. Cy., 15, 955-966, https://doi.org/10.1029/2000GB001382, 2001.

Apel, E. C. and UCAR/NCAR - Earth Observing Laboratory: Trace Organic Gas Analyzer (TOGA) for HIAPER. UCAR/NCAR - Earth Observing Laboratory, https://doi.org/10.5065/D6DF6P9Q, 2016.

Apel, E. C., Hills, A. J., Lueb, R., Zindel, S., Eisele, S., and Riemer, D. D.: A fast-GC/MS system to measure C2 to C4 carbonyls and methanol aboard aircraft, J. Geophys. Res.-Atmos., 108, 8794, https://doi.org/10.1029/2002JD003199, 2003. 
Apel, E. C., Brauers, T., Koppmann, R., Bandowe, B., Bossmeyer, J., Holzke, C., Tillmann, R., Wahner, A., Wegener, R., Brunner, A., Jocher, M., Ruuskanen, T., Spirig, C., Steigner, D., Steinbrecher, R., Alvarez, E. G., Muller, K., Burrows, J. P., Schade, G., Solomon, S. J., Ladstatter-Weissenmayer, A., Simmonds, P., Young, D., Hopkins, J. R., Lewis, A. C., Legreid, G., Reimann, S., Hansel, A., Wisthaler, A., Blake, R. S., Ellis, A. M., Monks, P. S., and Wyche, K. P.: Intercomparison of oxygenated volatile organic compound measurements at the SAPHIR atmosphere simulation chamber, J. Geophys. Res., 113, D20307, https://doi.org/10.1029/2008JD009865, 2008.

Apel, E. C., Emmons, L. K., Karl, T., Flocke, F., Hills, A. J., Madronich, S., Lee-Taylor, J., Fried, A., Weibring, P., Walega, J., Richter, D., Tie, X., Mauldin, L., Campos, T., Weinheimer, A., Knapp, D., Sive, B., Kleinman, L., Springston, S., Zaveri, R., Ortega, J., Voss, P., Blake, D., Baker, A., Warneke, C., Welsh-Bon, D., de Gouw, J., Zheng, J., Zhang, R., Rudolph, J., Junkermann, W., and Riemer, D. D.: Chemical evolution of volatile organic compounds in the outflow of the Mexico City Metropolitan area, Atmos. Chem. Phys., 10, 2353-2375, https://doi.org/10.5194/acp-10-2353-2010, 2010.

Apel, E. C., Olson, J. R., Crawford, J. H., Hornbrook, R. S., Hills, A. J., Cantrell, C. A., Emmons, L. K., Knapp, D. J., Hall, S., Mauldin III, R. L., Weinheimer, A. J., Fried, A., Blake, D. R., Crounse, J. D., Clair, J. M. St., Wennberg, P. O., Diskin, G. S., Fuelberg, H. E., Wisthaler, A., Mikoviny, T., Brune, W., and Riemer, D. D.: Impact of the deep convection of isoprene and other reactive trace species on radicals and ozone in the upper troposphere, Atmos. Chem. Phys., 12, 1135-1150, https://doi.org/10.5194/acp-12-1135-2012, 2012.

Arnold, F. and Hauck, G.: Lower stratosphere trace gas detection using aircraft-borne active chemical ionization mass spectrometry, Nature, 315, 307-309, 1985.

Arnts, R. R.: Reduction of Biogenic VOC Sampling Losses from Ozone via trans-2-Butene Addition, Environ. Sci. Technol., 42, 7663-7669, https://doi.org/10.1021/es800561j, 2008.

Atkinson, R.: Atmospheric chemistry of VOCs and $\mathrm{NO}_{x}$, Atmos. Environ., 34, 2063-2101, https://doi.org/10.1016/S13522310(99)00460-4, 2000

Baker, A., Sauvage, C., Thorentz U. R., van Velthoven, P., Oram, D. E., Zahn, A., Brenninkmeier, C. A. M., and Williams, J.: Evidence for strong, widespread chlorine radical chemistry associated with pollution outflow from continental Asia, Nat. Sci. Rep., 6, 36821, https://doi.org/10.1038/srep36821, 2016.

Bates, M. S., Gonzalez-Flesca, N., Sokhi, R., and Cocheo, V.: Atmospheric volatile organic compound monitoring. Ozone induced artefact formation, Environ. Monit. Asses., 65, 89-97, https://doi.org/10.1023/a:1006420412523, 2000.

Blake, R. S., Wyche, K. P., Ellis, A. M., and Monks, P. S.: Chemical ionization reaction time-of-flight mass spectrometry: Multi-reagent analysis for determination of trace gas composition, Int. J. Mass Spectrom., 254, 85-93, https://doi.org/10.1016/j.ijms.2006.05.021, 2006.

Bloss, C., Wagner, V., Jenkin, M. E., Volkamer, R., Bloss, W. J., Lee, J. D., Heard, D. E., Wirtz, K., Martin-Reviejo, M., Rea, G., Wenger, J. C., and Pilling, M. J.: Development of a detailed chemical mechanism (MCMv3.1) for the atmospheric oxidation of aromatic hydrocarbons, Atmos. Chem. Phys., 5, 641-664, https://doi.org/10.5194/acp-5-641-2005, 2005.
Colman, J. J., Swanson, A. L., Meinardi, S., Sive, B. C., Blake, D. R., and Rowland, F. S.: Description of the Analysis of a Wide Range of Volatile Organic Compounds in Whole Air Samples Collected during PEM-Tropics A and B, Anal. Chem., 73, 3723 3731, https://doi.org/10.1021/ac010027g, 2001.

Colomb, A., Williams, J., Crowley, J., Gros, V., Hofmann, R., Salisbury, G., Klüpfel, T., Kormann, R., Stickler, A., Forster, C., and Lelieveld, J.: Airborne Measurements of Trace Organic Species in the Upper Troposphere Over Europe: the Impact of Deep Convection, Environ. Chem., 3, 244-259, https://doi.org/10.1071/EN06020, 2006.

Crutzen, P. J., Williams, J., Pöschl, U., Hoor, P., Fischer, H., Warneke, C., Holzinger, R., Hansel, A., Lindinger, W., Scheeren, B., and Lelieveld, J.: High spatial and temporal resolution measurements of primary organics and their oxidation products over the tropical forests of Surinam, Atmos. Environ., 34, 1161-1165, 2000.

Fischbeck, G., Bönisch, H., Neumaier, M., Brenninkmeijer, C. A. M., Orphal, J., Brito, J., Becker, J., Sprung, D., van Velthoven, P. F. J., and Zahn, A.: Acetone-CO enhancement ratios in the upper troposphere based on 7 years of CARIBIC data: new insights and estimates of regional acetone fluxes, Atmos. Chem. Phys., 17, 1985-2008, https://doi.org/10.5194/acp-17-1985-2017, 2017.

Fischer, E. V., Jacob, D. J., Millet, D. B., Yantosca, R. M., and Mao, J.: The role of the ocean in the global atmospheric budget of acetone, Geophys. Res. Lett., 39, L01807, https://doi.org/10.1029/2011GL050086, 2012.

Gebhardt, S., Colomb, A., Hofmann, R., Williams, J., and Lelieveld, J.: Halogenated organic species over the tropical South American rainforest, Atmos. Chem. Phys., 8, 3185-3197, https://doi.org/10.5194/acp-8-3185-2008, 2008.

Goldan, P. D., Kuster, W. C., Fehsenfeld, F. C., and Montzka, S. A.: Hydrocarbon measurements in the southeastern United States: The Rural Oxidants in the Southern Environment (ROSE) program 1990, J. Geophys. Res., 100, 25945-25963, https://doi.org/10.1029/95jd02607, 1995.

Gostlow, B., Robinson, A. D., Harris, N. R. P., O’Brien, L. M., Oram, D. E., Mills, G. P., Newton, H. M., Yong, S. E., and A Pyle, J.: $\mu$ Dirac: an autonomous instrument for halocarbon measurements, Atmos. Meas. Tech., 3, 507-521, https://doi.org/10.5194/amt-3-507-2010, 2010.

Haagen-Smit, A. J., Bradley, C. E., and Fox, M. M.: Ozone formation in the photooxidation of organic substances, Ind. Eng. Chem., 9, 1484-1487, https://doi.org/10.1021/ie50525a044, 1956.

Hellen, H., Kuronen, P., and Hakola, H.: Heated stainless steel tube for ozone removal in the ambient air measurements of mono- and sesquiterpenes, Atmos. Environ., 57, 35-40, https://doi.org/10.1016/j.atmosenv.2012.04.019, 2012.

Hoker, J., Obersteiner, F., Bönisch, H., and Engel, A.: Comparison of GC/time-of-flight MS with GC/quadrupole MS for halocarbon trace gas analysis, Atmos. Meas. Tech., 8, 2195-2206, https://doi.org/10.5194/amt-8-2195-2015, 2015.

Holzinger, R., Williams, J., Salisbury, G., Klüpfel, T., de Reus, M., Traub, M., Crutzen, P. J., and Lelieveld, J.: Oxygenated compounds in aged biomass burning plumes over the Eastern Mediterranean: evidence for strong secondary production of methanol and acetone, Atmos. Chem. Phys., 5, 39-46, https://doi.org/10.5194/acp-5-39-2005, 2005. 
Hornbrook, R. S., Blake, D. R., Diskin, G. S., Fried, A., Fuelberg, H. E., Meinardi, S., Mikoviny, T., Richter, D., Sachse, G. W., Vay, S. A., Walega, J., Weibring, P., Weinheimer, A. J., Wiedinmyer, C., Wisthaler, A., Hills, A., Riemer, D. D., and Apel, E. C.: Observations of nonmethane organic compounds during ARCTAS - Part 1: Biomass burning emissions and plume enhancements, Atmos. Chem. Phys., 11, 11103-11130, https://doi.org/10.5194/acp-11-11103-2011, 2011.

Jacob, D. J., Field, B. D., Jin, E. M., Bey, I., Li, Q., Logan, J. A., Yantosca, R. M., and Singh, H. B.: Atmospheric budget of acetone, J. Geophys. Res.-Atmos., 107, ACH 5-1-ACH 5-17, https://doi.org/10.1029/2001JD000694, 2002.

Jäger, J.: Airborne VOC measurements on board the Zeppelin NT during PEGASOS campaigns in 2012 deploying the improved Fast-GC-MSD System, PhD, Forschungszentrum Jülich GmbH, Jülich, Germany, 2014.

Keppler, F., Harper, D. B., Röckmann, T., Moore, R. M., and Hamilton, J. T. G.: New insight into the atmospheric chloromethane budget gained using stable carbon isotope ratios, Atmos. Chem. Phys., 5, 2403-2411, https://doi.org/10.5194/acp-5-2403-2005, 2005.

Khan, M. A. H., Cooke, M. C., Utembe, S. R., Archibald, A. T., Maxwell, P., Morris, W. C., Xiao, P., Derwent, R. G., Jenkin, M. E., Percival, C. J., Walsh, R. C., Young, T. D. S., Simmonds, P. G., Nickless, G., O'Doherty, S., and Shallcross, D. E.: A study of global atmospheric budget and distribution of acetone using global atmospheric model STOCHEM-CRI, Atmos. Environ., 112, 269-277, https://doi.org/10.1016/j.atmosenv.2015.04.056, 2015.

Kley, D.: Tropospheric Chemistry and Transport, Science, 276, 1043-1044, https://doi.org/10.1126/science.276.5315.1043, 1997.

Laturnus, F., Haselmann, K. F., Borch, T., and Grøn, C.: Terrestrial natural sources of trichloromethane (chloroform, $\mathrm{CHCl} 3$ ) - An overview, Biogeochemistry, 60, 121-139, https://doi.org/10.1023/a:1019887505651, 2002.

Le Breton, M., McGillen, M. R., Muller, J. B. A., Bacak, A., Shallcross, D. E., Xiao, P., Huey, L. G., Tanner, D., Coe, H., and Percival, C. J.: Airborne observations of formic acid using a chemical ionization mass spectrometer, Atmos. Meas. Tech., 5, 30293039, https://doi.org/10.5194/amt-5-3029-2012, 2012.

Lee, J. H., Batterman, S. A., Jia, C. R., and Chernyak, S.: Ozone artifacts and carbonyl measurements using Tenex GR, Tenex TA, Carboparck B, and Carbopack X adsorbents, J. Air Waste Manage., 56, 1503-1517, 2006.

Lelieveld, J., Gromov, S., Pozzer, A., and Taraborrelli, D.: Global tropospheric hydroxyl distribution, budget and reactivity, Atmos. Chem. Phys., 16, 12477-12493, https://doi.org/10.5194/acp-1612477-2016, 2016.

Lerner, B. M., Gilman, J. B., Aikin, K. C., Atlas, E. L., Goldan, P. D., Graus, M., Hendershot, R., Isaacman-VanWertz, G. A., Koss, A., Kuster, W. C., Lueb, R. A., McLaughlin, R. J., Peischl, J., Sueper, D., Ryerson, T. B., Tokarek, T. W., Warneke, C., Yuan, B., and de Gouw, J. A.: An improved, automated whole air sampler and gas chromatography mass spectrometry analysis system for volatile organic compounds in the atmosphere, Atmos. Meas. Tech., 10, 291-313, https://doi.org/10.5194/amt-10-2912017, 2017.
Lobert, J. M., Keene, W. C., Logan, J. A., and Yevich, R.: Global chlorine emissions from biomass burning: Reactive chlorine emissions inventory, J. Geophys. Res., 104, 8373-8389, 1999.

Martín-Reviejo, M. and Wirtz, K.: Is Benzene a Precursor for Secondary Organic Aerosol?, Environ. Sci. Technol., 39, 10451054, https://doi.org/10.1021/es049802a, 2005.

Mastovska, K. and Lehotay, S. J.: Practical approaches to fast gas chromatography-mass spectrometry, J. Chromatogr. A, 1000, 153-180, 2003.

Molina, M. J. and Rowland, F. S.: Stratospheric sink for chlorofluoromethanes: chlorine atomc-atalysed destruction of ozone, $\mathrm{Na}$ ture, 249, 810-812, 1974.

Monks, P. S.: Gas-phase radical chemistry in the troposphere, Chem. Soc. Rev., 34, 376-395, https://doi.org/10.1039/B307982C, 2005.

Obersteiner, F., Bönisch, H., and Engel, A.: An automated gas chromatography time-of-flight mass spectrometry instrument for the quantitative analysis of halocarbons in air, Atmos. Meas. Tech., 9, 179-194, https://doi.org/10.5194/amt-9-179-2016, 2016a.

Obersteiner, F., Bönisch, H., Keber, T., O’Doherty, S., and Engel, A.: A versatile, refrigerant- and cryogen-free cryofocusingthermodesorption unit for preconcentration of traces gases in air, Atmos. Meas. Tech., 9, 5265-5279, https://doi.org/10.5194/amt9-5265-2016, 2016b.

Parrella, J. P., Jacob, D. J., Liang, Q., Zhang, Y., Mickley, L. J., Miller, B., Evans, M. J., Yang, X., Pyle, J. A., Theys, N., and Van Roozendael, M.: Tropospheric bromine chemistry: implications for present and pre-industrial ozone and mercury, Atmos. Chem. Phys., 12, 6723-6740, https://doi.org/10.5194/acp12-6723-2012, 2012.

Plass-Dülmer, C., Michl, K., Ruf, R., and Berresheim, H.: C-2-C8 hydrocarbon measurement and quality control procedures at the Global Atmosphere Watch Observatory Hohenpeissenberg, J. Chromatogr. A, 953, 175-197, https://doi.org/10.1016/s00219673(02)00128-0, 2002.

Plass-Dülmer, C., Schmidbauer, N., Slemr, J., Slemr, F., and D'Souza, H.: European hydrocarbon intercomparison experiment AMOHA part 4: Canister sampling of ambient air, J. Geophys. Res., 111, D04306, https://doi.org/10.1029/2005JD006351, 2006.

Pollmann, J., Ortega, J., and Helmig, D.: Analysis of atmospheric sesquiterpenes: Sampling losses and mitigation of ozone interferences, Environ. Sci. Technol., 39, 9620-9629, 2005.

Pollmann, J., Helmig, D., Hueber, J., Plass-Dülmer, C., and Tans, P.: Sampling, storage, and analysis of C2-C7 nonmethane hydrocarbons from the US National Oceanic and Atmospheric Administration Cooperative Air Sampling Network glass flasks, J. Chromatogr. A, 1188, 75-87, https://doi.org/10.1016/j.chroma.2008.02.059, 2008.

Pöschl, U., Williams, J., Hoor, P., Fischer, H., Crutzen, P. J., Warneke, C., Holzinger, R., Hansel, A., Jordan, A., Lindinger, W., Scheeren, H. A., Peters, W., and Lelieveld, J.: High Acetone Concentrations throughout the $0-12 \mathrm{~km}$ Altitude Range over the Tropical Rainforest in Surinam, J. Atmos. Chem., 38, 115-132, https://doi.org/10.1023/a:1006370600615, 2001.

Pusede, S. E. and Cohen, R. C.: On the observed response of ozone to $\mathrm{NO}_{x}$ and VOC reactivity reductions in San Joaquin Valley California 1995-present, Atmos. Chem. Phys., 12, 8323-8339, https://doi.org/10.5194/acp-12-8323-2012, 2012. 
Read, K. A., Mahajan, A. S., Carpenter, L. J., Evans, M. J., Faria, B. V. E., Heard, D. E., Hopkins, J. R., Lee, J. D., Moller, S. J., Lewis, A. C., Mendes, L., McQuaid, J. B., Oetjen, H., Saiz-Lopez, A., Pilling, M. J., and Plane, J. M. C.: Extensive halogen-mediated ozone destruction over the tropical Atlantic Ocean, Supplement, Nature, 453, 1232-1235, https://doi.org/10.1038/nature07035, 2008.

Rudolph, J., Khedim, A., Koppmann, R., and Bonsang, B.: Field study of the emissions of methyl chloride and other halocarbons from biomass burning in Western Africa, J. Atmos. Chem., 22, 67-80, https://doi.org/10.1007/bf00708182, 1995.

Saiz-Lopez, A., Lamarque, J.-F., Kinnison, D. E., Tilmes, S., Ordóñez, C., Orlando, J. J., Conley, A. J., Plane, J. M. C., Mahajan, A. S., Sousa Santos, G., Atlas, E. L., Blake, D. R., Sander, S. P., Schauffler, S., Thompson, A. M., and Brasseur, G.: Estimating the climate significance of halogen-driven ozone loss in the tropical marine troposphere, Atmos. Chem. Phys., 12, 3939-3949, https://doi.org/10.5194/acp-12-3939-2012, 2012.

Sala, S., Bönisch, H., Keber, T., Oram, D. E., Mills, G., and Engel, A.: Deriving an atmospheric budget of total organic bromine using airborne in situ measurements from the western Pacific area during SHIVA, Atmos. Chem. Phys., 14, 6903-6923, https://doi.org/10.5194/acp-14-6903-2014, 2014.

Scheeren, H. A., Lelieveld, J., de Gouw, J. A., van der Veen, C., and Fischer, H.: Methyl chloride and other chlorocarbons in polluted air during INDOEX, J. Geophys. Res.-Atmos., 107, INX2 1411-INX12 14-18, https://doi.org/10.1029/2001JD001121, 2002.

Scheeren, H. A., Lelieveld, J., Roelofs, G. J., Williams, J., Fischer, H., de Reus, M., de Gouw, J. A., Warneke, C., Holzinger, R., Schlager, H., Klüpfel, T., Bolder, M., van der Veen, C., and Lawrence, M.: The impact of monsoon outflow from India and Southeast Asia in the upper troposphere over the eastern Mediterranean, Atmos. Chem. Phys., 3, 1589-1608, https://doi.org/10.5194/acp-3-1589-2003, 2003.

Schiller, C. I., Bozem, H., Gurk, C., Parchatka, U., Königstedt, R., Harris, G. W., Lelieveld, J., and Fischer, H.: Applications of quantum cascade lazers for sensitive trace gas measurements of $\mathrm{CO}, \mathrm{CH}_{4}, \mathrm{~N}_{2} \mathrm{O}$ and HCHO, Appl. Phys. B, 92, 419-430, 2008.

Sprung, D. and Zahn, A.: Acetone in the upper troposphere/lowermost stratosphere measured by the CARIBIC passenger aircraft: Distribution, seasonal cycle, and variability, J. Geophys. Res.-Atmos., 115, D16301, https://doi.org/10.1029/2009JD012099, 2010.

Sprung, D., Jost, C., Reiner, T., Hansel, A., and Wisthaler, A.: Acetone and acetonitrile in the tropical Indian Ocean boundary layer and free troposphere: Aircraft-based intercomparison of APCIMS and PTR-MS measurements, J. Geophys. Res.-Atmos., 106, 28511-28527, https://doi.org/10.1029/2000JD900599, 2001.

Stohl, A., Hittenberger, M., and Wotawa, G.: Validation of the lagrangian particle dispersion model FLEXPART against largescale tracer experiment data, Atmos. Environ., 32, 4245-4264, https://doi.org/10.1016/S1352-2310(98)00184-8, 1998.

Streets, D. G., Yarber, K. F., Woo, J.-H., and Carmichael, G. R.: Biomass burning in Asia: Annual and seasonal estimates and atmospheric emissions, Global Biogeochem. Cy., 17, 1099, https://doi.org/10.1029/2003GB002040, 2003.

Tadic, I., Parchatka, U., Königstedt, R., and Fischer, H.: In-flight stability of quantum cascade laser-based infrared absorption spectroscopy measurements of atmospheric carbon monoxide, Appl. Phys. B, 123, 146, https://doi.org/10.1007/s00340-0176721-z, 2017.

Umezawa, T., Baker, A. K., Oram, D., Sauvage, C., O’Sullivan, D., Rauthe-Schöch, A., Montzka, S. A., Zahn, A., and Brenninkmeijer, C. A. M.: Methyl chloride in the upper troposphere observed by the CARIBIC passenger aircraft observatory: Large-scale distributions and Asian summer monsoon outflow, J. Geophys. Res.-Atmos., 119, 5542-5558, https://doi.org/10.1002/2013JD021396, 2014.

van der Werf, G. R., Randerson, J. T., Giglio, L., Collatz, G. J., Kasibhatla, P. S., and Arellano Jr., A. F.: Interannual variability in global biomass burning emissions from 1997 to 2004, Atmos. Chem. Phys., 6, 3423-3441, https://doi.org/10.5194/acp-6-34232006, 2006.

van der Werf, G. R., Randerson, J. T., Giglio, L., Collatz, G. J., Mu, M., Kasibhatla, P. S., Morton, D. C., DeFries, R. S., Jin, Y., and van Leeuwen, T. T.: Global fire emissions and the contribution of deforestation, savanna, forest, agricultural, and peat fires (1997-2009), Atmos. Chem. Phys., 10, 11707-11735, https://doi.org/10.5194/acp-10-11707-2010, 2010.

Velders, G. J. M., Fahey, D. W., Daniel, J. S., McFarland, M., and Andersen, S. O.: The large contribution of projected HFC emissions to future climate forcing, P. Natl. Acad. Sci. USA, 106, 10949-10954, https://doi.org/10.1073/pnas.0902817106, 2009.

Wang, S., Schmidt, J. A., Baidar, S., Coburn, S., Dix, B., Koenig, T. K., Apel, E., Bowdalo, D., Campos, T. L., Eloranta, E., Evans, M. J., DiGangi, J. P., Zondlo, M. A., Gao, R.-S., Haggerty, J. A., Hall, S. R., Hornbrook, R. S., Jacob, D., Morley, B., Pierce, B., Reeves, M., Romashkin, P., ter Schure, A., and Volkamer, R.: Active and widespread halogen chemistry in the tropical and subtropical free troposphere, P. Natl. Acad. Sci. USA, 112, 92819286, https://doi.org/10.1073/pnas.1505142112, 2015.

Wendisch, M., Pöschl, U., Andreae, M. O., et al.: The ACRIDICON-CHUVA campaign: Studying tropical deep convective clouds and precipitation over Amazonia using the new German research aircraft HALO, B. Am. Meteorol. Soc., 97, 1885-1908, https://doi.org/10.1175/BAMS-D-14-00255.1, 2016.

Williams, J.: Organic Trace Gases in the Atmosphere: An Overview, Environ. Chem., 1, 125-136, https://doi.org/10.1071/EN04057, 2004.

Williams, J., Yassaa, N., Bartenbach, S., and Lelieveld, J.: Mirror image hydrocarbons from Tropical and Boreal forests, Atmos. Chem. Phys., 7, 973-980, https://doi.org/10.5194/acp-7973-2007, 2007.

Yassaa, N., Song, W., Lelieveld, J., Vanhatalo, A., Bäck, J., and Williams, J.: Diel cycles of isoprenoids in the emissions of Norway spruce, four Scots pine chemotypes, and in Boreal forest ambient air during HUMPPA-COPEC-2010, Atmos. Chem. Phys., 12, 7215-7229, https://doi.org/10.5194/acp-127215-2012, 2012.

Yokelson, R. J., Andreae, M. O., and Akagi, S. K.: Pitfalls with the use of enhancement ratios or normalized excess mixing ratios measured in plumes to characterize pollution sources and aging, Atmos. Meas. Tech., 6, 2155-2158, https://doi.org/10.5194/amt6-2155-2013, 2013. 